\title{
TERRAS-RARAS NO ESTADO DE SÃO PAULO: AVALIAÇÃO DA POTENCIALIDADE GEOLÓGICA
}

\author{
IVAN SÉRGIO DE CAVALCANTI MELLO*, MARSIS CABRAL JÚNIOR*, \\ JOSE FRANCISCO MARCIANO MOTTA*
}

\begin{abstract}
RARE EARTH ELEMENTS IN SÃO PAULO STATE: A GEOLOGICAL EVALUATION. This paper evaluates the metallogenetic potential for REE (Rare-Earth Elements) of the State of São PauloBrazil. An exploration analysis model was based on a review of the pertinent bibliography (geology of São Paulo State and deposit types) followed by visits to Brazilian REE deposits. After these analyses, some potential areas have been checked through field and lab works (sampling, chemical and mineralogical analysis). The study concludes tha the State of São Paulo has a low potential for REE deposits. However, it indicates areas, such as the coastal plain in Cananeia-Iguape and Cenozoic aluvial sediments of the Pindamonhangaba Formation in the Paraíba Valley, where small placer deposits could occur.
\end{abstract}

Keywords: Rare earth, São Paulo, geological potential.

\begin{abstract}
RESUMO Este trabalho se constitui em um estudo metalogenético voltado à avaliação do potencial para ocorrência de depósitos de terras-raras (ETR) no Estado de São Paulo. O estudo envolveu a análise da tipologia dos depósitos mundiais dos ETR, visitas a jazidas brasileiras, formulação de modelos metalogenéticos, sua aferição através de campanha expedita de campo e a consideração de quesitos mineiros, econômicos e da legislação ambiental. Embcra o cenário geológico paulista esteja erguido sobre terrenos compatíveis com a existência dos principais metalotectos dos ETR, o potencial quanto a estes recursos minerais pode ser apontado como discreto. As perspectivas mais favoráveis estão relacionadas às faixas sedimentares litorâneas do sul paulista e às bacias continentais cenozóicas de Taubaté e São Paulo, compatíveis com mineralizações detríticas do tipo placer. A exequiibilidade econômica dos eventuais jazimentos deverá estar subordinada ao aproveitamento de bens minerais associados, pesados ou não (i.e. ilmenita, rutilo, zircão ou materiais industriais e para construção civil), e pelo contorno de limitações à explotação impostas por questões ambientais (zona costeira, principalmente) ou de conflito com outras formas de uso e ocupação do solo (bacias de São Paulo e Taubaté).
\end{abstract}

Palavras-chaves: Terras raras, São Paulo, potencial geológico.

INTRODUÇÃO Os terras-raras são 15 elementos metálicos, muito semelhantes em sua química elementar e com propriedades até há alguns anos pouco conhecidas. Começaram a ser descobertos na segunda metade do século 18 , e sua denominação decorre do aspecto terroso de seus óxidos e da suposição que seriam elementos pouco presentes na natureza (Abreu 1991). Os terras-raras, entretanto, são mais abundantes que um grande número de metais (i.e., zinco, cobre e níquel), e o mais escasso, o túlio, é mais abundante que a prata, o ouro e a platina somados.

A nomenclatura desses elementos tem sido muito discutida. Em meados deste século, o termo "lantanídios" foi proposto para evitar a noção de escassez que o nome terrasraras poderia induzir. Por sua vez, a Comissão de Nomenclatura da International Union of Pure and Applied Chemistry (TUPAC) recomenda os termos "metais de terras raras" para designar o escândio, o ítrio e os elementos de $n^{\circ}$ atômico 57 a 71 (lantanídeos). Nesta circunstância, o ítrio (Y) e o escândio (Sc) são associados aos lantanídeos, propriamente ditos, por terem características físicas e químicas bastante semelhantes a estes últimos.

Os elementos terras-raras (ETR) são constituintes de mais de 100 minerais. Em poucos destes, no entanto, ocorrem em concentrações que os qualificam como minerais de minério. Monazita-(Ce), bastnãsita-(Ce) e xenotímio-(Y) são, de longe, as mais importantes fontes destes elementos, já que $95 \%$, das reservas mundiais conhecidas (China, USA, Austrália, índia, Brasil, países africanos e do leste asiático) são formadas por estes minerais (Fig. 1). Constituindo exceções, no Canadá as reservas dos ETR se relacionam ao mineral gadolinita-(Y), enquanto que nos territórios correspondentes à antiga URSS as reservas dos ETR se associam ao mineral loparita-(Ce).

A importância econômica dos ETR decorre da especificidade de suas aplicações, seja por suas características químicas, relativamente comuns a todo o grupo de elementos, seja por suas propriedades físicas, caso em que se torna necessário individualiza-los. A investigação tecnológica sobre o uso dos ETR é constante e estimulada nos países desenvol-

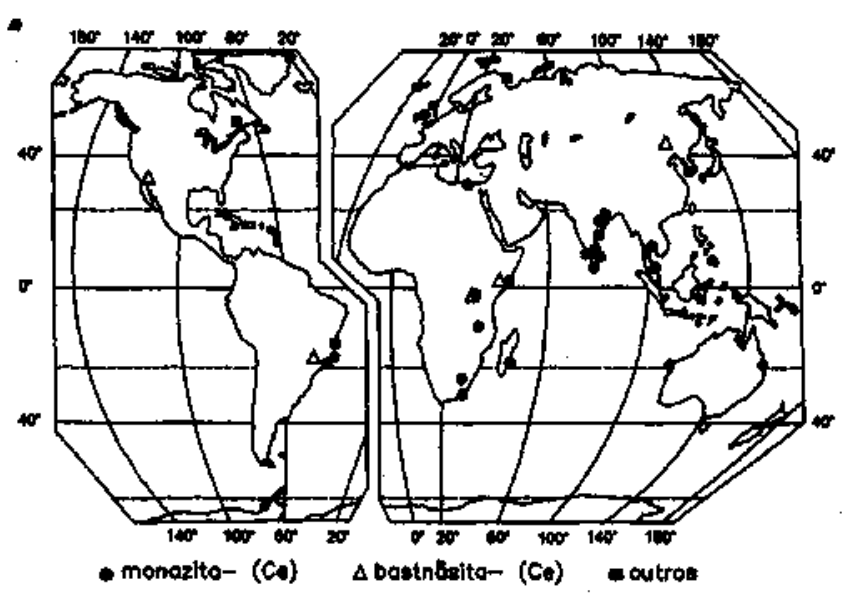

Figura 1 - Localização dos principais depósitos mundiais dos ETR

Figure 1 - Location of main world REE ore deposits 
vidos, principalmente pelas indústrias metalúrgica (aços, ligas metálicas), química (catalisadores, petróleo), cerâmica (supercondutores, pigmentos, vidros especiais) e eletrônica (raios X, tubos catódicos, fibras óticas, super-ímãs). A Figura 2 resume as principais aplicações industriais dos terras-raras.

NATUREZA DO TRABALHO Desenvolve-se aqui estudo metalogenético voltado à avaliação do potencial do Estado de São Paulo para ocorrência de depósitos de terrasraras (lantanídeos e ítrio). A distinção entre o ítrio e os demais metais de terras-raras decorre da apreciável dissociação entre os ambientes geológicos próprios às gerações mais expressivas do ítrio em relação aos lantanídeos. O escândio não é considerado em particular, por possuir características metalogenéticas bastante semelhantes às do ítrio e significado econômico bem mais discreto.

A avaliação da potencialidade paulista quanto aos ETR foi estabelecida a partir da tipologia dos depósitos mundiais destes elementos, visitas a jazidas brasileiras, formulação de análise metalogenética e sua aferição através de trabalhos de campo, além da consideração dos aspectos de economia mineral, das implicações das demais formas de uso e ocupação do solo, e das legislações mineira e ambiental quanto à explotação desses recursos nos terrenos potenciais de São Paulo.

ANÁLISE EXPLORATÓRIA A metalogenia dos ETR é bastante variada, fazendo com que estes elementos possam ocorrer em ambientes e metalotectos diversos, mais caracteristicamente a partir do Proterozóico Médio (Quadro 1).

A importância relativa dos vários tipos de depósitos dos ETR permite que se possa classificá-los como principais, subordinados e alternativos.

Os depósitos principais, com significado econômico real, relacionam-se a intrusivas alcalinas (depósitos primá- rios e secundários, de grande porte e teores elevados) e seqüências sedimentares detríticas (acumulações do tipo plácer). Ao final da década passada, embora apenas explotadas as jazidas de Bay an Obo (China) e Mountain Pass (EUA), carbonatitos mineralizados foram responsáveis por cerca de $70 \%$ da produção mundial dos ETR (Figueiredo Filho \& Torezan 1988, 1989). Ao mesmo tempo, pláceres, principalmente costeiros, respondiam pelo restante da produção mundial e pela totalidade da produção brasileira, apesar de também contar o País com grandes reservas associadas a alcalinas (i.e. Poços de Caldas e Araxá, MG, e Catalão, GO).

Depósitos subordinados possuem natureza diversificada. Séries granitóides calcioalcalinas a alcalinas especializadas podem apresentar cúpulas enriquecidas em ETR, a partir de alterações hidrotermais tardi a pós-magmáticas (Beus 1982, Drysdall et al. 1984). Neste caso, entretanto, o conteúdo dos ETR apenas adquire significado econômico quando submetido a processos naturais de concentração que possibilitem a formação de depósitos secundários elúvio-aluvionares. Nesta situação, os minerais dos ETR normalmente são subprodutos da lavra de cassiterita, volframita e columbita-tantalita. Também ocorrem depósitos subordinados em terrenos gnáissico-granitóides e de alto grau metamórfico, que podem apresentar mineralizações dos ETR em zonas de cisalhamento (Neary \& Highley 1984). Além disto, estes terrenos se constituem em fontes para concentrações detríticas secundárias, por apresentar a monazha-(Ce) como acessório freqüente na paragênese de seus litotipos mais comuns. Incluem-se também entre os depósitos subordinados pegmatitos granitóides mineralizados nos ETR (Laznicka 1985). No entanto, a exemplo do que se verifica com relação a cúpulas granitóides especializadas, estes corpos tendem a se comportar apenas como fontes para depósitos secundários dos ETR.

Depósitos alternativos correspondem a reservas técni$\operatorname{cas}^{\left({ }^{*}\right)}$ dos ETR existentes em fosforitos (Loureiro 1988), e

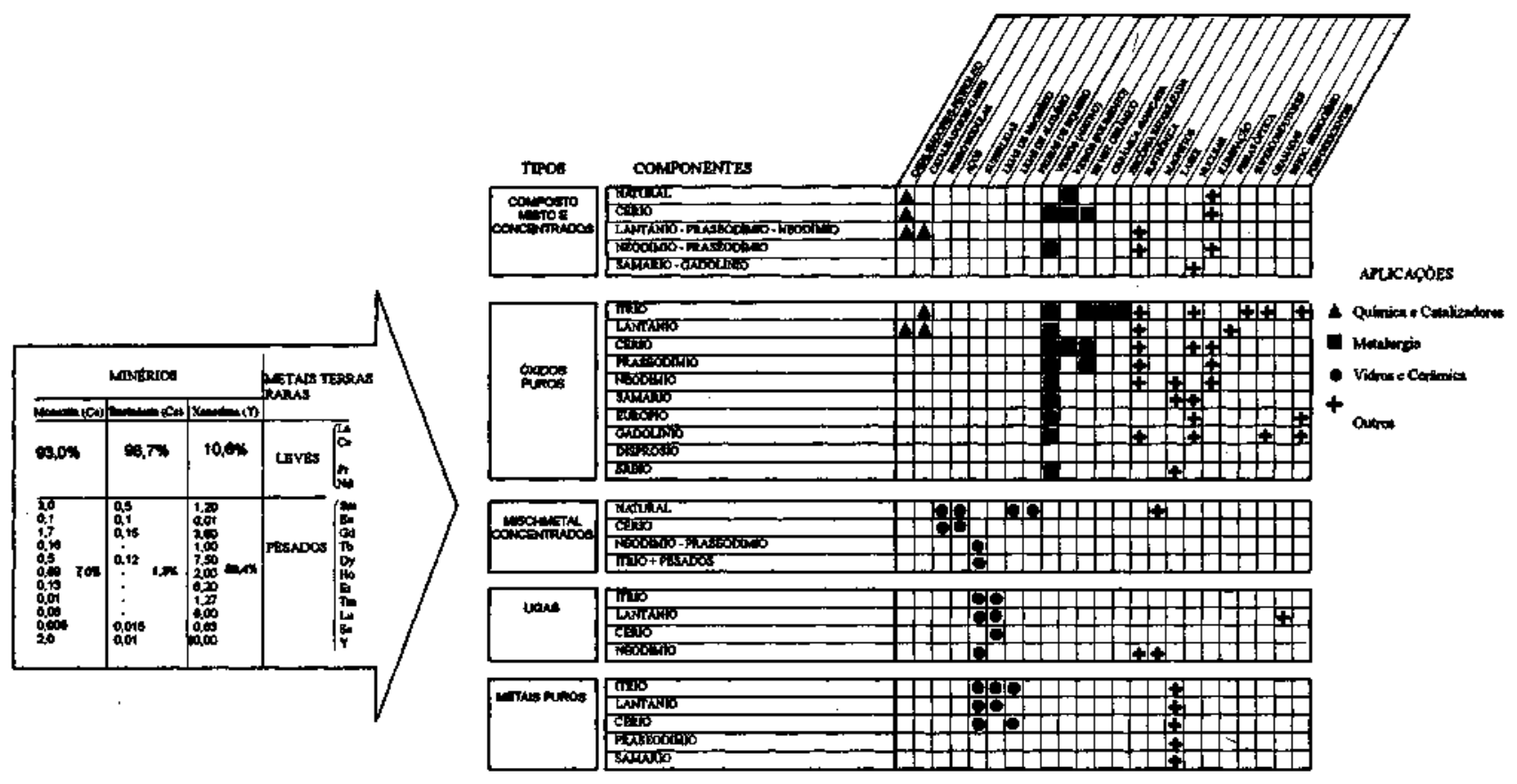

Figura 2 -Aplicações industriais dos terras-raras

Figure 2 - Industrial uses of REE

${ }^{(*)}$ Entende-se como reservas técnicas concentrações minerais subeconômicas, cuja perspectiva de aproveitamento depende do desenvolvimento de tecnologias de tratamento e extração. 
Quadro 1 - Tipologia dos depósitos de terras-raras

Chart 1 - REE deposit types

\begin{tabular}{|c|c|c|c|}
\hline Iutrustren Alenlinas & Placerea & Intrusivas Granitddes & Pegninatitos Granitóldes \\
\hline 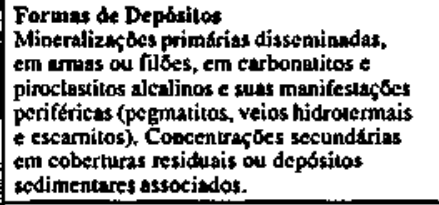 & 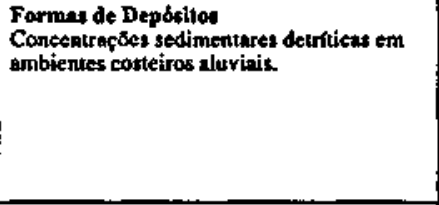 & 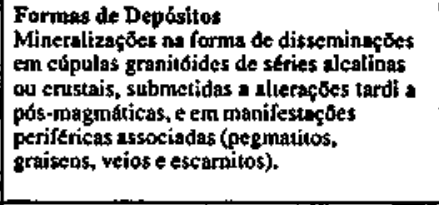 & 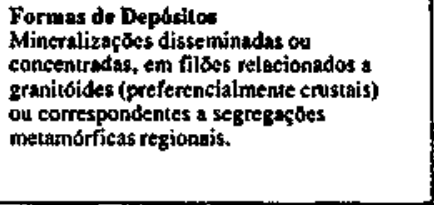 \\
\hline $\begin{array}{l}\text { Mtuersit de Minério } \\
\text { Bastoḱsitu-(Ce), monezion-(Ce), poiazita- } \\
\text { (Ce), rorecixitu(Ce), entre cutros. }\end{array}$ & $\begin{array}{l}\text { Minerati de Minerio } \\
\text { Monazita-(Ce) e xeatotimio-(Ce). }\end{array}$ & $\begin{array}{l}\text { Minerais de Mtinério } \\
\text { Xenodimio-(Y) e monazila-(Co). }\end{array}$ & 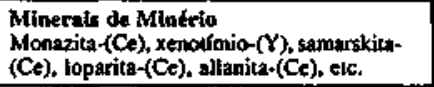 \\
\hline 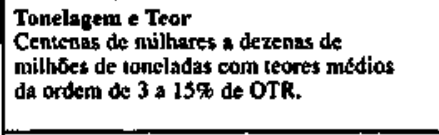 & $\begin{array}{l}\text { Tontlagem e Tear } \\
\text { Reservas variando de milhares a elguas } \\
\text { milhos de toneladas. Teores medios } \\
\text { variando de } 0.5 \text { a.45 de monazita pos } \\
\text { pesados }(0,0) * 0,12 \% \text { de OTR"). }\end{array}$ & $\begin{array}{l}\text { Tonelagem e Teor } \\
\text { Detenas a centeras de milhoes de } \\
\text { loneladas com teores Y entre } 0,03 \text { a } 0,5 \% \\
\text { e Ce entre } 0,01 \text { e } 0,3 \% \text {. }\end{array}$ & $\begin{array}{l}\text { Tonelogem } * \text { Tear } \\
\text { n.d. }\end{array}$ \\
\hline $\begin{array}{l}\text { Idade } \\
\text { Do Proterozdito Medio to Cenozdict. }\end{array}$ & $\begin{array}{l}\text { Idade } \\
\text { Essencialmenle no Cenozoico. }\end{array}$ & $\begin{array}{l}\text { Idode } \\
\text { Do tinal do Arqueano to Tercisrio. }\end{array}$ & $\begin{array}{l}\text { Idade } \\
\text { Essencialmenle no Put-Cambriano. }\end{array}$ \\
\hline 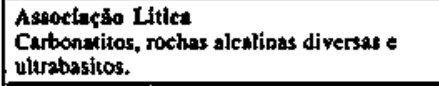 & $\begin{array}{l}\text { Ateocingis Litke } \\
\text { Artuitot e conglomerados. }\end{array}$ & $\begin{array}{l}\text { Astociasto Litlea } \\
\text { Sienilos, siemogranitos, granitose } \\
\text { àcaligranitos. }\end{array}$ & 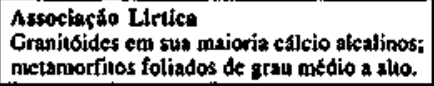 \\
\hline $\begin{array}{l}\text { Ambiente de Formaskio } \\
\text { Zonas de fraqueza em regides } \\
\text { Luracontidentals. }\end{array}$ & $\begin{array}{l}\text { Aprbienle de Formarga } \\
\text { Costeiros praiais e Curisis. }\end{array}$ & $\begin{array}{l}\text { Anabieute de Formasăo } \\
\text { Regioss peri e intracratônica. }\end{array}$ & 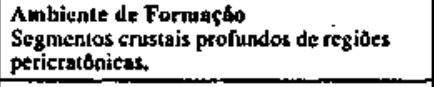 \\
\hline 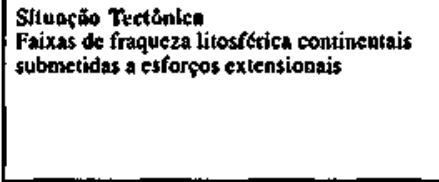 & 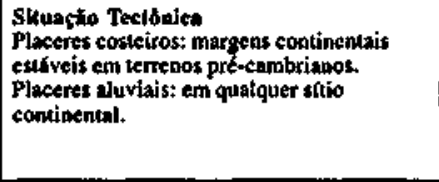 & 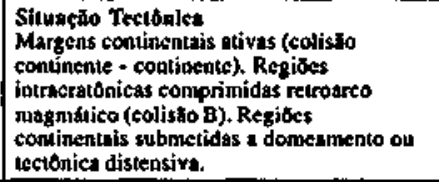 & 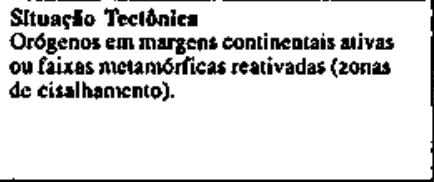 \\
\hline 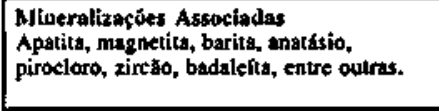 & 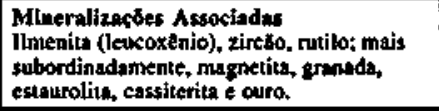 & 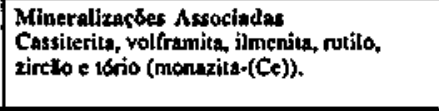 & $\begin{array}{l}\text { Mineralizagdes } \Lambda \text { ssocigdas } \\
\text { Tório, uraninila, colunibits-lanislita, } \\
\text { berilo, ilmenita, nutilo, zimsa. }\end{array}$ \\
\hline 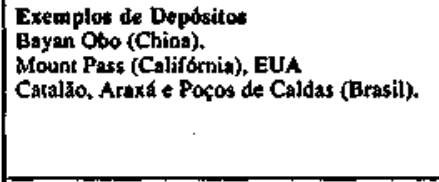 & 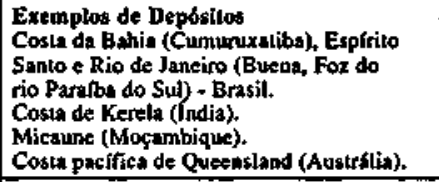 & $\begin{array}{l}\text { Exemplos de Deporlios } \\
\text { Escuto Ansbico, Maldsis, Nigtrin e } \\
\text { Rondboia. }\end{array}$ & 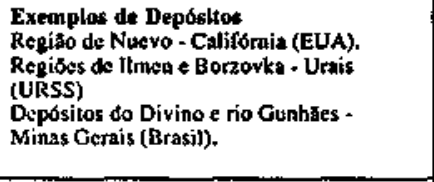 \\
\hline 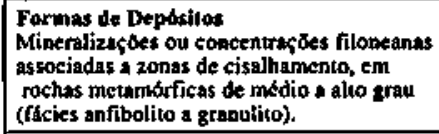 & 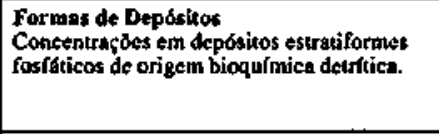 & $\begin{array}{l}\text { Formas de Depósitat } \\
\text { n.d }\end{array}$ & \multirow{8}{*}{ 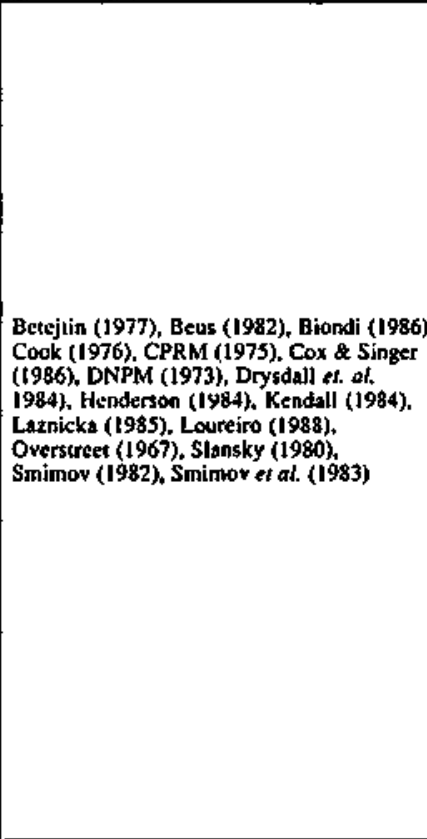 } \\
\hline 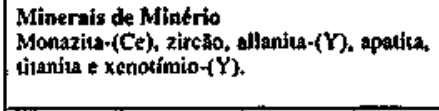 & $\begin{array}{l}\text { Mínerais de Minério } \\
\text { Colofana tica nos ETR. }\end{array}$ & 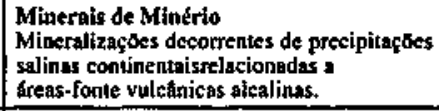 & \\
\hline 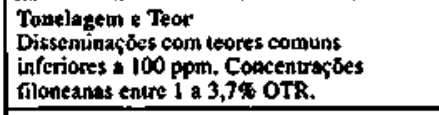 & $\begin{array}{l}\text { Tonelageme Tear } \\
\text { Teores variando de } 0,01 \text { a } 0,1 \$ \text {, podendo } \\
\text { chegar a te } \$ \text { \% de OTR. }\end{array}$ & $\begin{array}{l}\text { Tonelagem }=\text { Teur } \\
\text { n.d. }\end{array}$ & \\
\hline $\begin{array}{l}\text { Idade } \\
\text { Essencialmente no Pret-Cambriano }\end{array}$ & $\begin{array}{l}\text { Idade } \\
\text { Do Prd-Cambriana as Recente. }\end{array}$ & $\begin{array}{l}\text { Idade } \\
\text { Tercifín ao Recentc. }\end{array}$ & \\
\hline $\begin{array}{l}\text { Ascoctafio L Litica } \\
\text { Metantarfitos diversos de medio-alto grat, } \\
\text { granitodides diversos e pegmatios. }\end{array}$ & 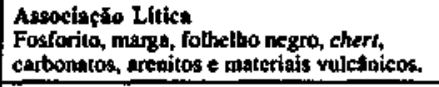 & $\begin{array}{l}\text { Associagto Littic } \\
\text { Canoadas sulinas assaciadas a seq thencias } \\
\text { terrigentus continentais e calefirios lacusares. }\end{array}$ & \\
\hline 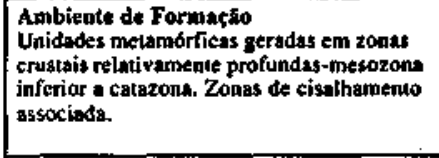 & 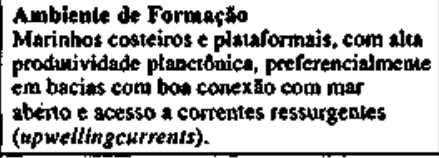 & $\begin{array}{l}\text { Ambiente de Formagtio } \\
\text { Bacias licustres - complexo4 playa lake. }\end{array}$ & \\
\hline $\begin{array}{l}\text { Situdatio Teelobict } \\
\text { Cinturbes orogenticos }\end{array}$ & $\begin{array}{l}\text { Siluarto Tettonico } \\
\text { Becias fntrapluea, ol demargens } \\
\text { coninentsis. }\end{array}$ & 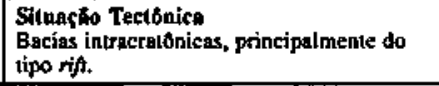 & \\
\hline $\begin{array}{l}\text { Mineralizapófs Associadas } \\
\text { Em deposilas Ciloneanos, associaçto com } \\
\text { galen. e apatita }\end{array}$ & $\begin{array}{l}\text { Minerglizagáex Assoelodas } \\
\text { Urałjo, ranAdio e molibdtatio. }\end{array}$ & $\begin{array}{l}\text { Mineralizagyoues Associadas } \\
\text { Sais diversom, fluorita, urtinio torio. }\end{array}$ & \\
\hline 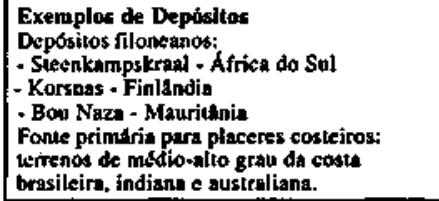 & $\begin{array}{l}\text { Exemplos de Depósitos } \\
\text { Naikope Mangyshlak (Ex-URSS). } \\
\text { Gcorgitia Besin (Ausirílis). }\end{array}$ & $\begin{array}{l}\text { Exemplos de Depostios } \\
\text { Lagos Natron e Magadj - Gregory Rifi } \\
\text { (Tanztnia e Kenia) }\end{array}$ & 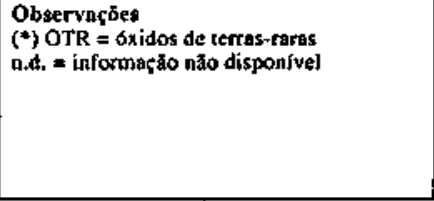 \\
\hline
\end{tabular}


evaporitos, a exemplo daqueles relacionados ao vulcanismo do Recente africano (Laznicka op.cit.).

PANORAMA DA GEOLOGIA PAULISTA O Estado de São Paulo é constituído essencialmente por um embasamento cristalino pré-cambriano a eo-paleozóico e por coberturas sedimentares fanerozóicas.

O conhecimento geológico sobre amplas faixas do Estado é ainda genérico, principalmente no que se refere aos terrenos pré-cambrianos, que sustentam controvérsias fundamentais envolvendo sua constituição lítica, estratigrafia e estruturação, e permitem interpretações díspares sobre aspectos geocronológicos, reconstituições paleoambientais e modelagens geotectônicas.

A natureza e a evolução dos terrenos fanerozóicos são presumivelmente mais simples. Estes resultam do desenvolvimento de bacias intraplaca, sendo representados por parte do segmento nordeste da Bacia do Paraná e do Sistema de Rifts da Serra do Mar (Almeida 1976) ou Rift Continental do Sudeste do Brasil (Riccomini 1989), e por coberturas cenozóicas costeiras e continentais em geral não muito expressivas.

Sendo necessária a elaboração de uma base geológica de referência para os diversos mapas temáticos utilizados na análise exploratória dos ETR, recorreu-se à cartografia das principais unidades litoestruturais do Estado de São Paulo (Fig.'3). A desvinculação desta base, de cunho eminentemente operacional, com significado estratigráfico-tectônico mais acurado, decorre das limitações do conhecimento geológico sobre áreas pré-cambrianas, conforme já citado. Isto, entretanto, não traz prejuízos consideráveis ao estudo, tendo em vista o caráter qualitativo e analógico adotado. De qualquer modo, no Quadro 2 mostra-se a correlação entre os conjuntos litoestruturais cartografados e as unidades geológicas formais mais freqüentemente descritas no Estado de São Paulo.

TERRENOS POTENCIAIS DO ESTADO DE SÃO PAULO Embora o cenário geológico estadual esteja montado sobre terrenos compatíveis com a existência dos principais metalotectos dos ETR, o único depósito conhecido, relativamente expressivo destes elementos, ocorre no manto de alteração residual dos carbonatitos situados em Barra do Itapirapuã, no médio vale do rio Ribeira. Ali se registram reservas da ordem de 2,4 milhões de toneladas de minério com 1,3\% de óxidos de terras-raras (Loureiro 1988, Loureiro et al. 1990). Além disto, há mineralizações em carbonatitos de Juquiá e Itanhaém (CBMM 1984), e depósitos de porte muito pequen ${ }^{(*)}$ em pláceres litorâneos, no sudeste do Estado (Tessler et al. 1985).

São tratados, em seguida, os terrenos estaduais paulistas favoráveis à ocorrência dos vários tipos de mineralizações dos ETR, com vista à análise da potencialidade de São Paulo quanto a estes bens minerais.

Intrusivas alcalinas As intrusivas alcalinas que ocorrem em São Paulo são representadas por 15 unidades, uma delas abrangente das várias manifestações do Litoral Norte do Estado (Fig. 4).

De modo geral, cada uma destas unidades compreende associações bastante variadas de rochas máfico-ultramáficas, alcalinas, peralcalinas e, eventualmente, carbonatitos.

Batólitos e stocks predominam como formas intrusivas. Diques ocorrem em menor escala, associados aos corpos maiores, ou isoladamente, caso mais característico de Itanhaém (CBMM 1984). As alcalinas de Jaboticabal-

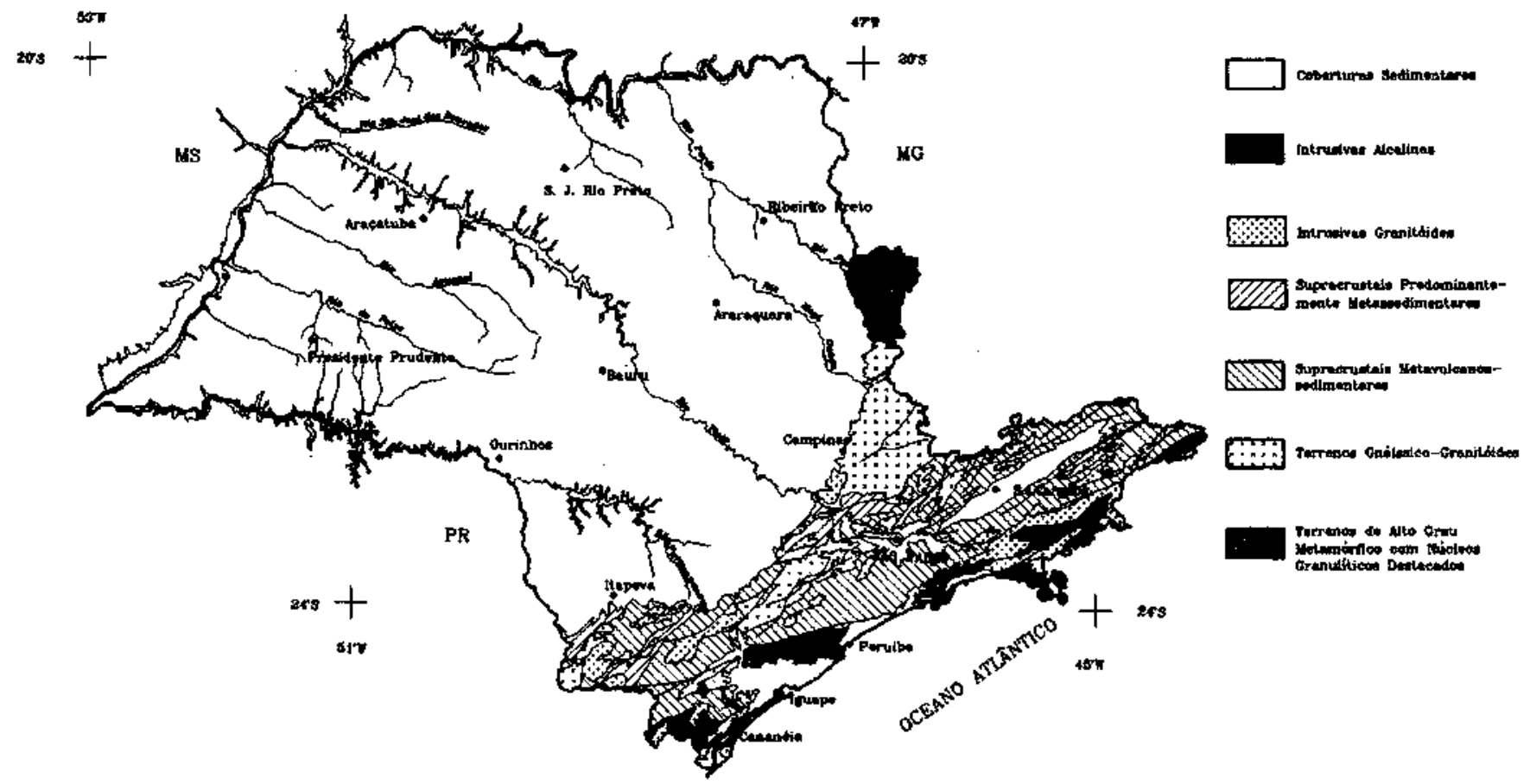

Figura 3 - Principais unidades litoestruturais do Estado de São Paulo Figure 3 - Main lithostructural units of State of São Paulo State

(**) Laznicka (1985) considera depósitos de pequeno porte aqueles com conteúdo de monazita-(Ce) na faixa de $20.000 \mathrm{t}$, de médio porte com $100.000 \mathrm{t}$ a 200.0001 e grandes depósitos com mais de 1.000 .000 t, os teores do mineral sempre variando entre $0,5 \%$ e $4 \%$ da fração pesada. 


\begin{tabular}{|c|c|c|c|c|c|c|c|c|}
\hline \multirow{3}{*}{\multicolumn{2}{|c|}{ UNIDADES LITOESTRUTURAIS }} & \multirow{3}{*}{ ARQUEANO } & \multicolumn{6}{|c|}{ UNIDADES LITOESTRATIOGRAFICAS } \\
\hline & & & \multicolumn{3}{|c|}{ PROTEROZOOICO } & \multicolumn{3}{|c|}{ FENEROZOICO } \\
\hline & & & INFERIOR & MÉDIO & SUPERIOR & PALEOZÓICo & MESOZOICO & CENOZÓICO \\
\hline \multirow[b]{2}{*}{$\begin{array}{l}\text { UNIDADES } \\
\text { CRISTALINAS } \\
\text { BASAIS }\end{array}$} & $\begin{array}{c}\text { TERRENOS DE ALTO } \\
\text { GRAU } \\
\text { METAMORFICO }\end{array}$ & $\begin{array}{l}\text { Complexo Costeiro } \\
\text { (IPT 1981a) } \\
\text { Complexo Varginha } \\
\text { (IPT 198Ia) } \\
\text { ? }\end{array}$ & $\begin{array}{l}\text { Complexo Paralba do Sul/Parte } \\
\text { (IPT 1981 a) }\end{array}$ & & 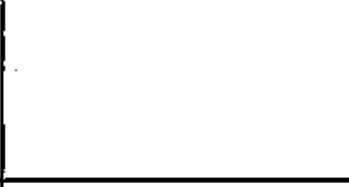 & & & \\
\hline & $\begin{array}{c}\text { TERRENOS } \\
\text { GNAISSICO- } \\
\text { GRANITOIDES }\end{array}$ & <- & $\begin{array}{l}\text { Complexo Partiba do SulParte } \\
\text { (IPT 1981 1a) } \\
\text { Complexo Amparo } \\
\text { (IFT 1981a) }\end{array}$ & $<-\infty-\infty$ & $\begin{array}{l}\text { Sufles Granficas Indiferenciadd, } \\
\text { Migmat(fica c Cantareira-Pante } \\
\text { (Hasui et at. 1978. IPT 1981a) }\end{array}$ & . & & \\
\hline \multirow{3}{*}{$\begin{array}{l}\text { SUPRACRISTAIS } \\
\text { METAMORFIZADAS }\end{array}$} & $\begin{array}{l}\text { PREDOMINANTE- } \\
\text { MENTE METAS- } \\
\text { SEDMENTARES }\end{array}$ & $\begin{array}{l}\text { Complexo Juiz de Fora } \\
\text { (IPT 198 Ia) } \\
\end{array}$ & 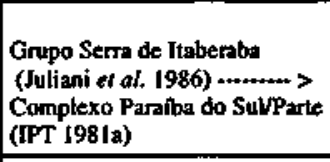 & $\begin{array}{l}\text { Formacia Seluva } \\
\text { (IPT 1988b) } \\
\text { Fommaça Perau } \\
\text { (IPT 1981a) } \\
\end{array}$ & $\begin{array}{l}\text { Complexo Emb+1 } \\
\text { (IPT 1981a) }\end{array}$ & & & \\
\hline & $\begin{array}{l}\text { METAYULCANOS- } \\
\text { SEDIMENTARES }\end{array}$ & & & $\begin{array}{l}\text { Formaçao Iporangs } \\
\text { (IPT 1988b) } \\
\end{array}$ & 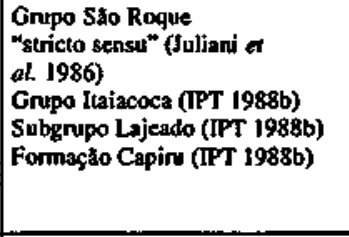 & & & \\
\hline & $\begin{array}{l}\text { TIPO } \\
\text { "MOLASSA" }\end{array}$ & & & & $\begin{array}{l}\text { Formaģăa Sagrambaia, Quatis, } \\
\text { Eleutério, Salto de Pirapota } \\
\text { (IPT, } 198 \text { in c 1981 ib) }\end{array}$ & & & \\
\hline \multirow{3}{*}{ INTRUSIVAS } & \begin{tabular}{|l|l} 
A & INTRUSIVAS \\
CRANITÓIDES \\
C & SIN A TARDI \\
& TECTONICAS \\
\end{tabular} & & & & $\begin{array}{l}\text { Suíte Granítica Cantartira/Parte } \\
\text { (Hasui et al. 1978. IPT 1981a) }\end{array}$ & & & \\
\hline & \begin{tabular}{|l|l|} 
D & INTRUSIVAS \\
A & GRANITOLOLES \\
S & TECTONARICAS A \\
& ANOROGLAICAS \\
\end{tabular} & & & & $\begin{array}{l}\text { Suíles Graníticas Graciosa, Itu e } \\
\text { Granoffirica (Hasui 1978, 1981a) } \\
\text { Sufte Serra do Mar (Kau; 1984) }\end{array}$ & & & \\
\hline & ALCALINAS & & & & & & $\begin{array}{l}\text { Intrusivas alcalinase } \\
\text { carbonautitos }\end{array}$ & \\
\hline $\begin{array}{l}\text { COBERTURAS } \\
\text { SEDIMENTARES }\end{array}$ & & & & & & 8 & - Bacia do Parans - & $\begin{array}{l}\text { Sistema de rifles da } \\
\text { Serra do Mor } \\
\text { Unidades sedimentares } \\
\text { da Provincia Costeira } \\
\text { Coberturas aluvjonares } \\
\text { Continentais }\end{array}$ \\
\hline
\end{tabular}



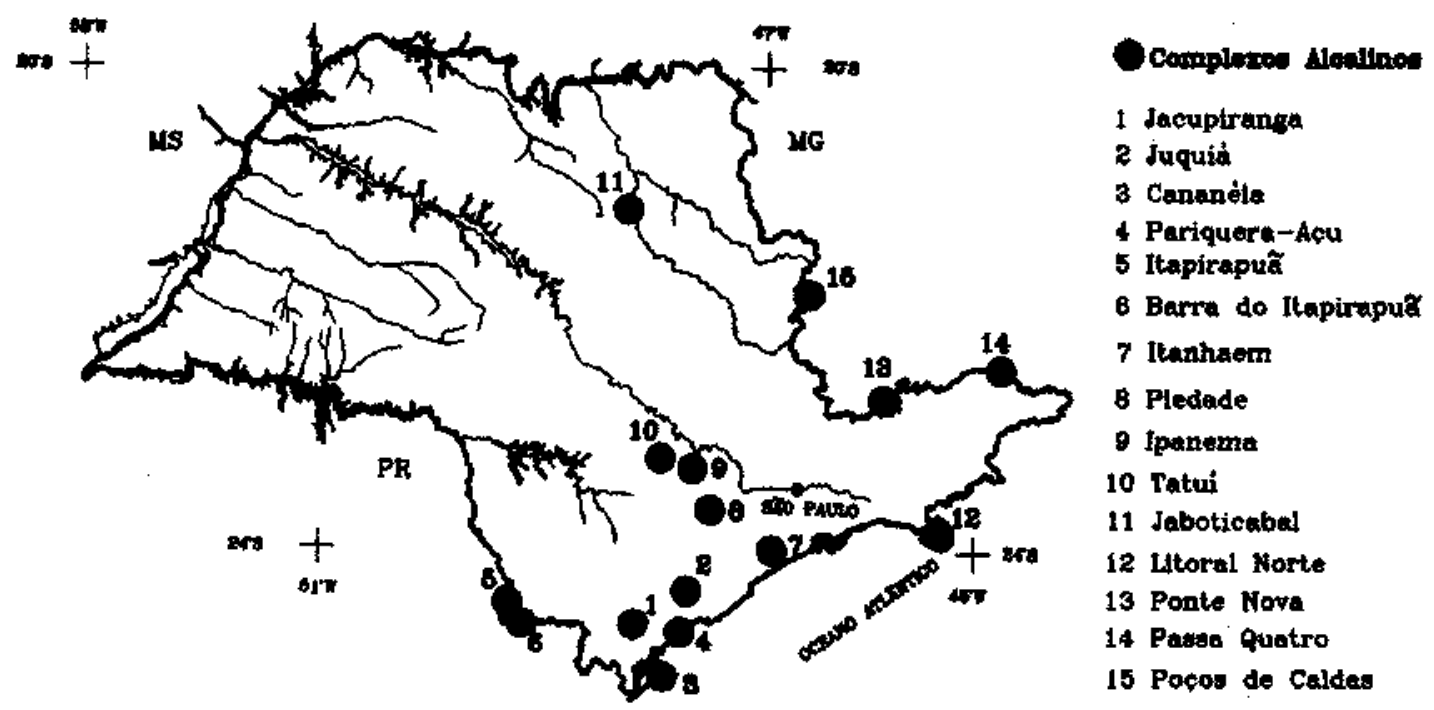

Figura 4 - Intrusivas alcalinas do Estado de São Paulo

Figure 4 - Alkaline intrusions of the State São Paulo

Taiaçu, por sua vez, incluem termos eruptivos equivalentes a fonólitos e lavas analcimíticas subaflorantes, intercalados em arenitos cretácicos do Grupo Bauru (Coutinho et al. 1981).

Carbonatitos ocorrem mais expressivamente nos complexos de Jacupiranga, Juquiá e Barra do Itapirapua (Melcher 1966, Born 1971, Loureiro et. al. 1989). Apresentam-se bastante subordinados em Itapirapua (CPRM 1975) e sob a forma de diques em Itanhaem (CBMM op. cit.) e Ipanema (Nogueira Filho et al. 1978).

Em vista da grande diversidade dos tipos de depósitos que podem ser cogitados para este ambiente, a existência de mineralizações conhecidas, a presença de carbonatitos e a ocorrência de capeamento residual expressivo passam a ser preponderantes para atribuição de maior potencialidade quanto a depósitos não-descobertos. As demais características geológicas são importantes para indicação da natureza dos possíveis metalotectos (Quadro 3).

Em relação às mineralizações conhecidas, foram antes citadas as reservas existentes nos carbonatitos de Barra do Itapirapua. No Complexo de Juquiá e nos carbonatitos de Itanhaem, por sua vez, há mineralizações primárias, representadas por indícios de monazita-(Ce) e bastnãsita-(Ce), respectivamente registradas por Born (1971) e CBMM (1984). Quanto aos demais complexos, os dados disponíveis qualificam-nos como estéreis. No maciço de Poços de Caldas, os depósitos se situam no Estado de Minas Gerais.

Pláceres Nestes metalotectos, os minerais enriquecidos em ETR, normalmente monazita-(Ce) e xenotímio-(Y), se concentram em sedimentos detríticos areno-rudáceos.

No Estado de São Paulo, o registro sedimentar compatível com estes depósitos está basicamente inserido em terrenos fanerozóicos (Fig. 5). Horizontes pré-cambrianos (i.e. Grupo São Roque, Complexo Turvo-Cajati) carecem de estudos que definam a distribuição, estratigrafia e os ambientes deposicionais das possíveis seqüências de interesse. Além disto, é discreto o registro de mineralizações dos ETR em pláceres antigos.
Deste modo, as três províncias geológicas de São Paulo a serem necessariamente consideradas são a Bacia do Paraná, o Sistema de Rifts da Serra do Mar e a Planície Costeira. Um quarto compartimento corresponde às planícies aluvionares quaternárias, apenas tratadas de modo particular quando fora das demais províncias.

A Bacia do Paraná ocupa dois terços do Estado de São Paulo, abrangendo sedimentos do Devoniano ao Cenozóico e uma vasta gama de sedimentos detríticos continentais e costeiros. Com relação ao potencial de mineralização aluvial, é imperativa a necessidade de proximidade dos horizontes concentradores com uma área-fonte enriquecida. Neste sentido, passam a ter mais significado a sedimentação Bauru ao redor de núcleos alcalinos (i.e. região de Jaboticabal) e os sedimentos da borda da Bacia (i.e. Formação Furnas). Devem ainda ser considerados os litotipos costeiros permocarboníferos (parte das unidades Rio Bonito, Tietê e Itararé-Aquidauana), que constituem, por si só, armadilhas faciológicas eficientes, mesmo a distâncias maiores de áreas-fonte.

O Sistema de Rifts da Serra do Mar abrange as bacias terciárias de Taubaté, de São Paulo, e o Graben de Sete Barras (Melo 1989), e envolve uma sedimentação continental eminentemente detrítica. $\mathrm{O}$ caráter tectônico e os produtos sedimentares evidenciam uma relação estreita do sítio deposicional com áreas-fonte pré-cambrianas. Por outro lado, seus conjuntos areno-rudáceos de topo e os aluviões quaternários encaixados nestes compartimentos hospedam concentrações de minerais pesados que incluem a monazita(Ce), a exemplo do que ocorre na região de Tremembé (Ribeiro Filho 1958), no vale do rio Paraíba. Desta forma, horizontes areno-conglomeráticos fluviais são metalotectos potenciais para concentração de pesados.

Quanto à região costeira, verifica-se que o litoral paulista se apresenta bastante distinto em seus segmentos norte e sul. $\mathrm{Na}$ porção setentrional desta faixa, as serranias précambrianas estão juntas ao mar, ocasionando o desenvolvimento de pequenas enseadas. Ao sul, a linha de costa se apresenta retilínea, com as escarpas serranas quase sempre mais afastadas da orla. Neste trecho, a planície costeira 


\begin{tabular}{|c|c|c|c|c|c|c|c|c|c|}
\hline \multirow{2}{*}{$\begin{array}{l}\text { Nome do } \\
\text { Complexo }\end{array}$} & \multirow{2}{*}{$\begin{array}{l}\text { Localizaçào no } \\
\text { Mapa Tematico }\end{array}$} & \multirow{2}{*}{ Ärea $\left(\mathrm{km}^{2}\right)$} & \multirow{2}{*}{$\begin{array}{l}\text { Associaçắo } \\
\text { Litica }\end{array}$} & \multirow{2}{*}{$\begin{array}{l}\text { Manto } \\
\text { de Alteraçāo }\end{array}$} & \multicolumn{3}{|c|}{ Mineralizaçōes de ETR } & \multirow{2}{*}{$\begin{array}{l}\text { Natureza dos } \\
\text { Possiveis Depositos }\end{array}$} & \multirow{2}{*}{$\begin{array}{l}\text { Bibliografia } \\
\text { Consultada }\end{array}$} \\
\hline & & & & & Indicio & Ocortência & Depósito & & \\
\hline Jacupiranga & 1 & 65,0 . & $\begin{array}{l}\text { Carbonatitos, jacupiranguitos, } \\
\text { piroxenitos, nefelina sienitos, } \\
\text { sienitos, peridotitos, ijolitos, } \\
\text { tinguaitos }\end{array}$ & Inexistente & $\cdots$ & -- & $\cdots$ & $\begin{array}{l}\text { Alunionar; disseminaçōes } \\
\text { em filöes periféricos }\end{array}$ & $\begin{array}{l}\text { CBMM (1984) } \\
\text { Melcher (1966) }\end{array}$ \\
\hline Juquía & 2 & 13,5 & $\begin{array}{l}\text { Carbonatitos, piroxenitos, } \\
\text { peridotitos, jjolitos, pulasquitos, } \\
\text { sienitos, nefelina sienitos, } \\
\text { tinguaílos, lamprófiros } \\
\end{array}$ & $\begin{array}{l}\text { Solos residuais com } \\
\text { espessura média de } 15 \mathrm{~m}\end{array}$ & $\mathbf{x}$ & $\cdots$ & $\cdots$ & $\begin{array}{l}\text { Residual; aluvionar; } \\
\text { disseminą̧ăa em fildes } \\
\text { periféricos }\end{array}$ & $\begin{array}{l}\text { Born (1971) } \\
\text { CBMM (1984) }\end{array}$ \\
\hline Cananéia & 3 & 1,5 & $\begin{array}{l}\text { Sienitos, fonslitos, tinguaitos, } \\
\text { pulasquitos }\end{array}$ & - & $\cdots$ & $\cdots$ & $\cdots$ & Placeres costeiros & $\begin{array}{l}\text { CPRM (1975) } \\
\text { IPT (1981a) } \\
\end{array}$ \\
\hline Pariqülera-Açu & 4 & 6,0 & $\begin{array}{l}\text { Shonquinitos, malignitos, } \\
\text { nefelina-sienitos. Cataclasitos } \\
\text { marginais. Pegmatitos periféricos }\end{array}$ & $\begin{array}{l}\text { Solos residuais pouco } \\
\text { expressivos }\end{array}$ & $\cdots$ & $\cdots$ & $\cdots$ & $\begin{array}{l}\text { Residual; aluvionar; } \\
\text { disseminaçăo em filoses } \\
\text { periféricos }\end{array}$ & $\begin{array}{l}\text { Fermeira et ah } \\
\text { (1987) }\end{array}$ \\
\hline Itapi rapua & 5 & 4,5 & $\begin{array}{l}\text { Cabonatitos, nefelina sienitos, } \\
\text { meltegitos }\end{array}$ & & $\cdots$ & $\cdots$ & $\cdots$ & $\begin{array}{l}\text { Residual; aluvionar; } \\
\text { disseminaçăto em filoes } \\
\text { periféricos }\end{array}$ & $\begin{array}{l}\text { CBPRM (1975) } \\
\text { CBMM (1984) } \\
\text { Loureiro \&l at } \\
\text { (1989) }\end{array}$ \\
\hline $\begin{array}{l}\text { Barrado } \\
\text { Itapirapuã }\end{array}$ & 6 & 2,0 & $\begin{array}{l}\text { Carbonatitos, piroxenitos, } \\
\text { silexitos }\end{array}$ & & $\cdots$ & $\cdots$ & $\mathrm{x}$ & $\begin{array}{l}\text { Disseminaços primárias; } \\
\text { residual; aluvionar; } \\
\text { disseminaçסes em } \\
\text { filoes periféricos } \\
\end{array}$ & $\begin{array}{l}\text { CBMM (1984) } \\
\text { Lourneiro et aL } \\
\text { (1989) }\end{array}$ \\
\hline Itanhaém & $\boldsymbol{T}$ & & $\begin{array}{l}\text { Carbonatitos tinguaítos, } \\
\text { shonquinitos }\end{array}$ & . & $\mathrm{x}$ & $\cdots$ & $\cdots$ & $\begin{array}{l}\text { Disseminaç̃es primárias; } \\
\text { residual; flionar, } \\
\text { aluvionar }\end{array}$ & $\begin{array}{l}\text { CBMM (1984) } \\
\text { Ulbrich \& Gomes } \\
\text { (1981) }\end{array}$ \\
\hline Piedade & 8 & 1,0 & Shonquinitos & & $\cdots$ & -- & --- & $\begin{array}{l}\text { Residual; aluvionar; } \\
\text { disseminaçōes en fildes } \\
\text { internos ou perifericos }\end{array}$ & IPT (1981a) \\
\hline Ipanema & 9 & 9,0 & $\begin{array}{l}\text { Glimeritos, Sienjtos, piroxenitos } \\
\text { pulasquitos, nordmarquitos. Veios } \\
\text { de carbonalitos }\end{array}$ & $\begin{array}{l}\text { Solos residuais com até } \\
17 \mathrm{~m}\end{array}$ & -- & $\cdots$ & $\cdots$ & $\begin{array}{l}\text { Residual; aluvionar; } \\
\text { disseminą̧os em filoes } \\
\text { perifericos }\end{array}$ & CBMM (1984) \\
\hline Tatuf & 10 & & & & $\cdots$ & $\cdots$ & $\cdots$ & Residual; aluvionar & $\begin{array}{l}\text { CBMM (1984) } \\
\text { IPT (1981b) }\end{array}$ \\
\hline Jaboticabal & 11 & $\begin{array}{c}100 \\
\text { (subnatlorante) }\end{array}$ & $\begin{array}{l}\text { Analcima fonólitos, lavas } \\
\text { analcimíticas }\end{array}$ & Inexistente & $\cdots$ & $\cdots$ & $\cdots$ & $\begin{array}{l}\text { Sedimentar, em } \\
\text { arenitos sotopostos }\end{array}$ & $\begin{array}{l}\text { Coutinho et al. } \\
\text { (1981) } \\
\text { IPT (1981a) }\end{array}$ \\
\hline $\begin{array}{l}\text { ltha do Litoral } \\
\text { Norte } \\
\end{array}$ & 12 & 150 & $\begin{array}{l}\text { Nefelina sienitos, pulasquilos, } \\
\text { teralitos, essexitos. Diques diversos } \\
\end{array}$ & $\begin{array}{l}\text { Solos residuais pouco } \\
\text { expressivos }\end{array}$ & $\cdots$ & $\cdots$ & $\cdots$ & $\begin{array}{l}\text { Disseminaçōes em filbes } \\
\text { internos; placeres costeiros }\end{array}$ & IPT (1981a) \\
\hline Ponte Nova & 13 & 2,5 (em SP) & $\begin{array}{l}\text { Tinguaítos, shonquinitos } \\
\text { monshiquitos }\end{array}$ & $\begin{array}{l}\text { Solos residuais pouco } \\
\text { expressivos }\end{array}$ & $\cdots$ & $\cdots$ & $\cdots$ & $\begin{array}{l}\text { Disseminaçסes em filotes } \\
\text { internos ou periféricos; } \\
\text { aluvionar }\end{array}$ & IPT (1981a) \\
\hline Passa Quatro & 14 & $70(\mathrm{em} \mathrm{SP})$ & $\begin{array}{l}\text { Nefelina sienitos, pulasquilos, } \\
\text { sienitos e granilos alcalinos. } \\
\text { Diques de fonólitos } e \text { tinguaftos. }\end{array}$ & $\begin{array}{l}\text { Solos residuais com ate } \\
15 \mathrm{~m}\end{array}$ & * & $\cdots$ & $\cdots$ & $\begin{array}{l}\text { Residual; aluvionar; } \\
\text { disseminaço em filoes } \\
\text { internos ou periféricos }\end{array}$ & $\begin{array}{l}\text { Sigolo (1979) } \\
\text { IPT (1981a) }\end{array}$ \\
\hline Pogos de Caldas & 15 & $80(\mathrm{em} \mathrm{SP})$ & $\begin{array}{l}\text { Foisitos, fondlitos, tinguailos } \\
\text { nefelina sienitos, lujaritos }\end{array}$ & $\begin{array}{l}\text { Solos residuais com até } \\
\text { is } \mathrm{m}\end{array}$ & $\cdots$ & $\cdots$ & $\cdots$ & $\begin{array}{l}\text { Residual; aluvionar; } \\
\text { disseminaçăo em filoes } \\
\text { internos ou peritericos }\end{array}$ & $\begin{array}{l}\text { IPT (1981a) } \\
\text { Moniz (1984) }\end{array}$ \\
\hline
\end{tabular}




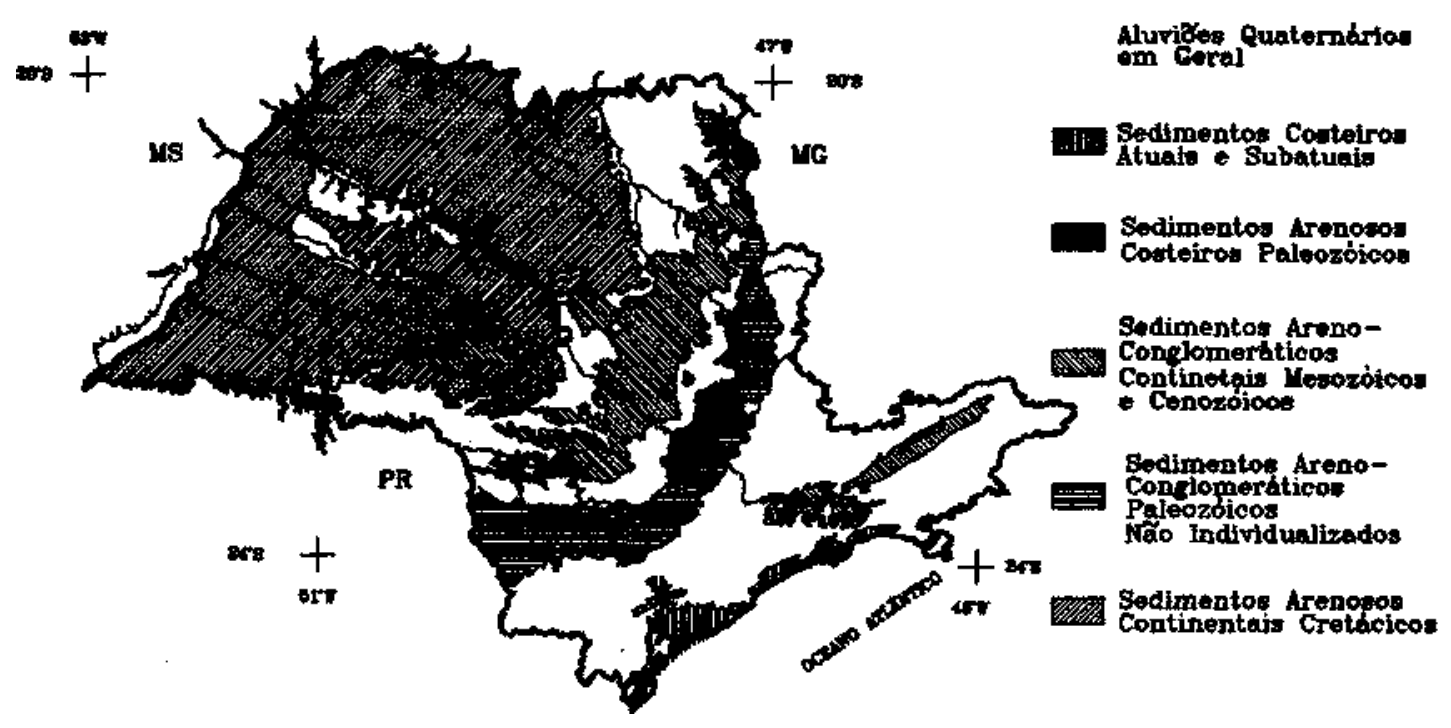

Figura 5 - Distribuição das unidades sedimentares compatíveis com depósitos tipo placer no Estado de São Paulo Figure 5 - Sedimentary units with potential for placer deposits in State of São Paulo

mostra melhor desenvolvimento, constituindo paisagem expressiva na região de Iguape-Cananéia. O embasamento é composto por terrenos gnáissico-granitóides e faixas de alto grau metamórfico. Ocorrem também intrusivas granitóides e alcalinas subordinadas, além de pegmatites, o que constitui associação lítica ordinariamente enriquecida em minerais dos ETR, com destaque para a monazita-(Ce).

O conteúdo sedimentar da planície possui caráter aluvial e marinho costeiro, resultando de uma evolução que remonta ao Terciário, durante a manifestação de vários ciclos erosivos e deposicionais.

O baixo vale do rio Ribeira registra a ocorrência de três fases aluviais distintas, além da própria bacia fluvial heje instalada, com seus respectivos depósitos atuais e subatuais (Melo 1990). Todo esse registro sedimentar, sobretudo os mais antigos (Formação Pariqüera-Açu e terraços encaixados), denota um virtual potencial de pré-concentração de monazita-(Ce) para abastecimento posterior às fácies costeiras.

$\mathrm{O}$ registro de fácies costeiras é abundante na planície. Destaca-se a Formação Cananéia pela grande área que ocupa no trecho Cananéia-Iguape, posicionando-se nas porções mais interiores do sistema ilha-barreira atual.

É grande também a expressão das praias atuais e préatuais. Estes sedimentos se caracterizam como lençóis de areias finas incoesas, limpas, estratificadas, de ambiente praial, com fácies eólicas associadas. Exibem ainda termos mais grossos, que poderão estar associados a canais costeiros (inlet) ou eventos tempestuosos (washoverfans).

No contexto apresentado, verifica-se a interrelação entre diversos ciclos aluviais e costeiros, a presença de áreasfonte virtualmente possuidoras de minerais dos ETR, submetidas a intemperismo durante fases climáticas quentes e úmidas, e a freqüente ocorrência de concentração de pesados, que formam, em alguns casos, pequenos depósitos. Explica-se, deste modo, a existência de mineralizações dos ETR em pláceres nos segmentos mais desenvolvidos da planície, local com boas perspectivas quanto a depósitos não- descobertos, sobretudo nos trechos Cananéia-Iguape e Itanhaém.
Em relação aos aluviões quaternários, muito embora a rede de drenagem atual apresente ampla distribuição geográfica no Estado, planícies aluvionares bem desenvolvidas estão restritas a alguns rios, encontrando-se, geralmente, condicionadas a seleiras litoestruturais do substrato rochoso. O preenchimento sedimentar do fundo desses vales reflete o caráter meandrante do sistema atual, estando representado por sedimentos inconsolidados (areias e cascalhos silicosos, siltes e argilas), freqüentemente capeados por matéria orgânica. Este perfil-tipo da sedimentação mais recente encontra-se, por vezes, capeando ou entalhando gerações mais antigas de aluviões. Os minerais pesados, quando presentes, se concentram sobretudo junto aos pacotes arenosos das barras aluviais e cascalhos basais.

Em geral, como atestam os depósitos residuais desta natureza, a concentração econômica de minerais dos ETR em pláceres aluviais depende de uma fonte enriquecida bastante próxima (geralmente a menos de $10 \mathrm{~km}$ ), o potencial deste metalotecto varia de acordo com a área-fonte, seu principal controlador. Dessa forma, os prospectos mais interessantes no Estado são representados pelos aluviões posicionados dentro ou nas proximidades dos metalotectos primários (intrusivas alcalinas, intrusivas granitóides especializadas, províncias pegmatíticas, e terrenos gnáissicogranitóides e de alto grau metamórfico).

O Quadro 4 relaciona as unidades sedimentares enfocadas e suas principais características geológicas.

Intrusivas granitóides Mineralizações dos ETR associadas a granitos (lato sensu) se relacionam com séries intrusivas calcioalcaliftas a alcalinas especializadas.

Em São Paulo, no entanto, permanecem ausentes dados que possibilitem a efetiva caracterização petroquímica e petrogenética de boa parte dos corpos granitóides do embasamento cristalino do Estado.

$\mathrm{Na}$ falta de classificações mais recentes e amplas, granitos (lato sensu) com as características necessárias à metalogenia dos ETR (Fig. 6) deverão estar incluídos entre as Suítes Itu e Graciosa de Hasui et al (1978), a Suíte Serra do Mar de Kaul et al (1982) e Kaul (1984), que inclui 
Quadro 4 - Unidades sedimentares e parâmetros geológicos considerados na avaliação da potencialidade paulista quanto a depósitos tipo placer de terras-raras Chart 4 - Sedimentary units and their potential for REE placer deposits

\begin{tabular}{|c|c|c|c|c|c|c|c|c|c|}
\hline \multirow{2}{*}{\multicolumn{2}{|c|}{ UNIDADE }} & \multirow{2}{*}{ IDADE } & \multirow{2}{*}{$\begin{array}{l}\text { DOMÍNIOS } \\
\text { - Ambiental } \\
\text { • Climático }\end{array}$} & \multirow{2}{*}{$\begin{array}{l}\text { ASSOCIAÇÃO LÍTICA OU } \\
\text { SEDIMENTAR }\end{array}$} & \multicolumn{2}{|c|}{$\begin{array}{l}\text { ÁREA FONTE DE } \\
\text { INTERESSE }\end{array}$} & \multicolumn{2}{|c|}{$\begin{array}{l}\text { OCORRÊNCIA } \\
\text { S }\end{array}$} & \multirow{2}{*}{$\begin{array}{l}\text { BIBLIOGRAFIA } \\
\text { CONSULTADA }\end{array}$} \\
\hline & & & & & TIPO & $\begin{array}{c}\text { PRE } \\
\text { CONCENTRADO }\end{array}$ & 0 & $\mathbf{D}$ & \\
\hline & ALUVIÕES ATUAIS & $\mathrm{H}$ & - Fluvial & Areias, cascalhes, siltes, argilas e turfas & \begin{tabular}{l|}
$(\mathrm{A})$ \\
$(\mathrm{H})$ \\
$(\mathrm{GG})$ \\
$(\mathrm{G})$ \\
$(\mathrm{P})$
\end{tabular} & ? & & & \multirow[t]{10}{*}{$\begin{array}{l}\text { IPT (1981a,1988c); } \\
\text { Melo (1990) } \\
\text { Riccomini (1990) }\end{array}$} \\
\hline & PRAIAS ATUAIS & $\mathrm{H}$ & $\begin{array}{l}- \text { Praia } \\
- \text { Quente e úmido }\end{array}$ & $\begin{array}{l}\text { Areias de praias finas, limpas, localmente com } \\
\text { cores escuras (pesados) }\end{array}$ & $\begin{array}{c}\mathrm{A} \\
\mathrm{H} \\
\mathrm{GG} \\
\mathrm{G}\end{array}$ & $\begin{array}{l}(\mathrm{D} \\
(2) \\
(3)\end{array}$ & $\mathrm{x}$ & $\mathrm{x}$ & \\
\hline \multirow{3}{*}{$\begin{array}{l}\mathrm{B} \\
\mathrm{A} \\
\mathrm{C} \\
\mathrm{I} \\
\mathrm{A} \\
\mathrm{C} \\
\mathrm{O} \\
\mathrm{S} \\
\mathrm{T} \\
\mathrm{E} \\
\mathrm{I} \\
\mathrm{R} \\
\mathrm{A}\end{array}$} & FORMAÇÃO CANANÉIA (1) & Q & $\begin{array}{l}\text { - Praia/Duna } \\
\text { - Quente e úmido }\end{array}$ & $\begin{array}{l}\text { Lençol arenoso fino, limpo, estruturado em } \\
\text { cordões subparalelos à costa atual }\end{array}$ & $\begin{array}{c}\mathrm{A} \\
\mathrm{H} \\
\mathrm{GG} \\
\mathrm{G}\end{array}$ & $\begin{array}{l}(2) \\
(3)\end{array}$ & $\mathrm{x}$ & & \\
\hline & TERRAÇOS (2) & TQ & $\begin{array}{l}- \text { Aluvial } \\
- \text { Seco }\end{array}$ & Cascalhes e areias & \begin{tabular}{c|}
$(\mathrm{A})$ \\
$(\mathrm{H})$ \\
$(\mathrm{GG})$ \\
$(\mathrm{G})$
\end{tabular} & (3) & $\mathrm{x}$ & & \\
\hline & $\begin{array}{l}\text { FORMAÇAO PARIQUERA- } \\
\text { AÇU (3) }\end{array}$ & $\mathrm{T}$ & $\begin{array}{l}\text { - Leques aluviais, fluvial e lacustre } \\
\text { - Umido }\end{array}$ & Conglomerados, areias, silte e argilas & $\begin{array}{c}(\mathrm{A}) \\
(\mathrm{H}) \\
(\mathrm{GG}) \\
(\mathrm{G})\end{array}$ & $\begin{array}{l}(2) \\
(3)\end{array}$ & - & & \\
\hline \begin{tabular}{|l}
$\mathrm{R}$ \\
$\mathrm{I}$ \\
$\mathrm{F}$ \\
$\mathrm{T}$ \\
$\mathrm{E}$ \\
$\mathrm{S}$
\end{tabular} & $\begin{array}{l}\text { BACIAS SÃO PAULO, } \\
\text { TAUBATE E SETE BARRAS }\end{array}$ & $\mathrm{T}$ & $\begin{array}{l}\text { - Leques aluviais, fluvial e } \\
\text { - Lacuste (playa lake) } \\
\text { - Semi-árido na base, úmido } \\
\text { no topo }\end{array}$ & $\begin{array}{l}\text { Arenitos médios, conglomerados, lamitos } \\
\text { subparalelos à costa atual }\end{array}$ & $\begin{array}{c}(\mathrm{P}) \\
(\mathrm{GG}) \\
(\mathrm{G}) \\
(\mathrm{A})\end{array}$ & $?$ & $\mathrm{x}$ & & \\
\hline \begin{tabular}{|l|l}
$\mathrm{B}$ \\
$\mathrm{A}$ \\
$\mathrm{C}$ \\
$\mathrm{I}$
\end{tabular} & $\begin{array}{l}\text { FORMAÇÃO ITAQUERI } \\
\text { MARÍLIÁ COBERTURAS } \\
\text { CENOZÓICAS }\end{array}$ & K-T & $\begin{array}{l}\text { - Leques aluviais e fluviais } \\
\text { - Semi-árido }\end{array}$ & Conglomerados, arenitos lamíticos e lamitos & $\begin{array}{l}(\mathrm{A}) \\
(\mathrm{GG}) \\
(\mathrm{H})\end{array}$ & $?$ & & & \\
\hline $\begin{array}{l}\text { A } \\
D \\
0\end{array}$ & $\begin{array}{l}\text { FORMAÇÃO CAIUA, SANTO } \\
\text { ANASTÁCIO, ADAMANTINA } \\
\text { (parte) }\end{array}$ & $\mathrm{K}$ & $\begin{array}{l}\text { - Fluvio-desértico } \\
\text { - Semi-árido }\end{array}$ & Arenitos, arenitos lamíticos e lamitos & (A) & - & & & \\
\hline $\begin{array}{l}\mathrm{P} \\
\mathrm{A} \\
\mathrm{R}\end{array}$ & $\begin{array}{l}\text { FORMAÇÕES, RIO BONITO, } \\
\text { TIETÊ, TATUI (parte) e } \\
\text { GRUPO ITARARÉ (parte) }\end{array}$ & $\mathrm{P}$ & $\begin{array}{l}\text { - Costeiro } \\
\text { - Úmido }\end{array}$ & $\begin{array}{l}\text { Arenitos, arenitos conglomeráticos, lamitos e } \\
\text { camadas orgânicas }\end{array}$ & $?$ & $?$ & & & \\
\hline $\mathrm{N}$ & $\begin{array}{l}\text { SUBGRUPO ITARARÉ (parte) } \\
\text { e GRUPO TUBARÃO (parte) }\end{array}$ & C-P & $\begin{array}{l}\text { - Diversificado: continental, } \\
\text { costeiro e marinho } \\
\text { - Predominantemente frio com } \\
\text { fases úmidas }\end{array}$ & $\begin{array}{l}\text { Arenitos, arenitos conglomeráticos, pelitos, } \\
\text { diamictitos, etc. }\end{array}$ & $\begin{array}{l}\mathrm{GG}) \\
(\mathrm{H}) \\
(\mathrm{G})\end{array}$ & - & & & \\
\hline
\end{tabular}




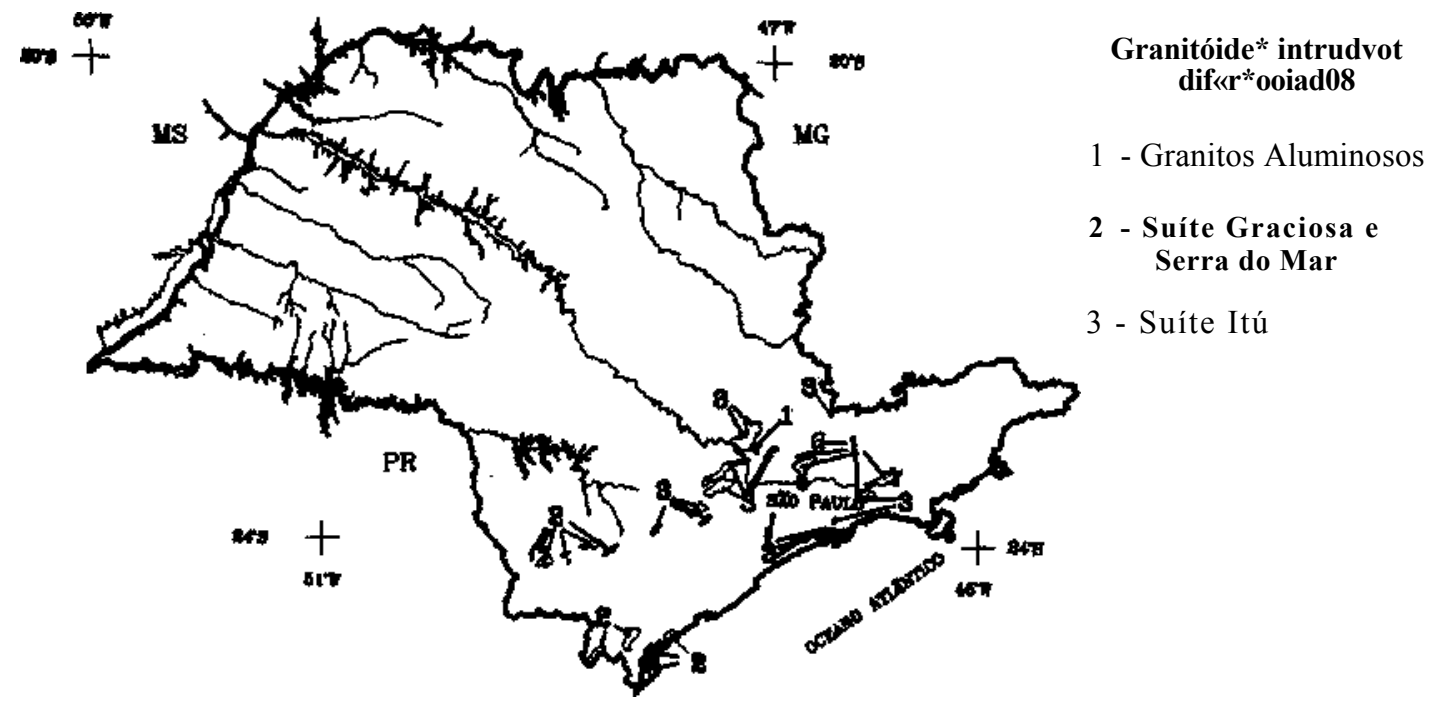

Figura 6 - Intrusivas granitoides diferenciadas do Estado de São Paulo

Figure 6 - Granitic intrusive rocks in the State of São Paulo

toda a Suíte Graciosa de Hasui et al (op. cit.), e entre os granites crustais caracterizados por Wernick \& Gallembeck (1986). Todos esses plutonitos são considerados de idades variáveis desde o Proterozóico Superior ao Eo-Paleozóico (Quadro 5).

A potencialidade destes corpos é bastante imprecisa, já que os parâmetros essencialmente químicos e petrográficos utilizados para sua classificação não lhes garantem especialização metalogenética ou a preservação das mineralizações porventura associadas às suas cúpulas. De qualquer modo, a análise metalogenética para os ETR não é sensivelmente prejudicada em decorrência da importância secundária destes metalotectos.

Pegmatites granitoides Segundo IPT (1984a), as ocorrências de pegmatitos no Estado de São Paulo concentram-se em sete regiões distintas, a saber: Embu-Guaçu, Mogi das Cruzes, Santa Branca, São Luiz do Paraitinga, Bananal, Perus, Guarulhos e Socorro (Fig. 7).
Os pegmatitos paulistas são predominantemente dos tipos simples e recristalizados, segundo a classificação de Smirnov (1982). Possuem composição mineralógica essencialmente quartzo-feldspática, que inclui ainda moscovita, biotita e turmalina preta. Subordinadamente, ocorrem corpos portadores de granada, rubelita, berilo, lepidolita, ambligonita, espodumênio, cassiterita e minerais de tório e urânio. Estes últimos pegmatitos, mais diferenciados (pegmatitos complexos), são raros e pontuais, situando-se, em geral, nas regiões de Perus-Guarulhos, Mogi da Cruzes e, mais raramente, em São Luiz do Paraitinga (Quadro 6).

A análise da potencialidade das províncias pegmatíticas de São Paulo deve considerar duas possibilidades. A primeira é a existência de concentrações detríticas embutidas nas províncias citadas, independentemente da natureza daqueles corpos. A segunda, mais conjectural, é a ocorrência de mineralizações em áreas do embasamento favoráveis à ocorrência de pegmatitos não descobertos, nas cercanias das provincias já conhecidas.

Quadro 5-Intrusivas granitoides de São Paulo e parâmetros geológicos de potencialidade quanto aos ETR Chart 5 - Intrusive granitic rocks in São Paulo State and their potential for REE deposits

\begin{tabular}{|c|c|c|c|c|}
\hline $\begin{array}{l}\text { INTRUSIVAS } \\
\text { GRANITOIDES }\end{array}$ & LITOTIPOS & IDADE & $\begin{array}{l}\text { NATUREZA DOS } \\
\text { POSSÍVEIS DEPÓSITOS }\end{array}$ & $\begin{array}{l}\text { BIBLIOGRAFIA } \\
\text { CONSULTADA }\end{array}$ \\
\hline $\begin{array}{l}\text { Suítes Graciosa e Serra do } \\
\text { Mar (i.e granites Mandira, } \\
\text { Guaraú, Sguário, } \\
\text { Campina do Veado) }\end{array}$ & $\begin{array}{l}\text { Granitos a sienitos } \\
\text { (riebeckita granito aegerina- } \\
\text { granitos, aegerina-riebeckita } \\
\text { granitos, sienitos, quartzo- } \\
\text { sienitos sódicos }\end{array}$ & \multirow{3}{*}{$\begin{array}{l}\text { Neoproterozóico ao } \\
\text { Eopaleozóico }\end{array}$} & \multirow{3}{*}{$\begin{array}{l}\text { Placeres aluviais, } \\
\text { juntamente com Sn, W, Nb } \\
\text { e Ta. Menos prováveis, } \\
\text { disseminações em cúpulas, } \\
\text { escarnitos e filões periféricos }\end{array}$} & $\begin{array}{l}\text { Hasui et al. (1978) } \\
\text { IPT (1981a) } \\
\text { Kauletal. }(1982) \\
\text { Kaul (1984) }\end{array}$ \\
\hline $\begin{array}{l}\text { Granitos Aluminosos } \\
\text { Crustais (granitos } \\
\text { Salesópolis, Cantareira } \\
\text { Perus, Mairiporã, Nazaré } \\
\text { Paulista e Cachoeira }\end{array}$ & $\begin{array}{l}\text { Monzogranitos a } \\
\text { granodiorios }\end{array}$ & & & $\begin{array}{l}\text { Wernick \& Galembeck } \\
\text { (1986) }\end{array}$ \\
\hline $\begin{array}{l}\text { Suíte Itu (i.e. granitos } \\
\text { Itu, São Francisco, Pilar } \\
\text { do Sul, São Miguel } \\
\text { Arcanjo, Parati }\end{array}$ & $\begin{array}{l}\text { Monzogranitos a } \\
\text { granodiorios }\end{array}$ & & & $\begin{array}{l}\text { Hasui et al. (1978) } \\
\text { IPT (1981a) }\end{array}$ \\
\hline
\end{tabular}


Quadro 6-Natureza e parâmetros para avaliação de potencialidade, quanto aos ETR das províncias pegmatíticas de São Paulo Chart 6 - Pegmatitic areas in São Paulo State and their potential for REE deposits

\begin{tabular}{|c|c|c|c|c|c|c|c|c|}
\hline $\begin{array}{l}\text { AREAS COM } \\
\text { CONCENTRAÇOES } \\
\text { DE PEGMATITOS }\end{array}$ & $\begin{array}{c}\text { TIPOS } \\
\text { PREDOMINANTES }\end{array}$ & CONTEXTO GEOLÓGICO & $\begin{array}{l}\text { ROCHAS } \\
\text { HOSPEDEIRAS }\end{array}$ & $\begin{array}{l}\text { TIPO DE } \\
\text { CONTATO }\end{array}$ & $\begin{array}{c}\text { FORMA } \\
\text { DOMINANTE }\end{array}$ & $\begin{array}{l}\text { MINERA- } \\
\text { LOGIA }\end{array}$ & $\begin{array}{l}\text { DMMENSOES } \\
\text { DOS coRPOS } \\
\text { - espessura } \\
\text { comptimento }\end{array}$ & $\begin{array}{c}\text { BIBLIOGRAFTA } \\
\text { CONSULTADA }\end{array}$ \\
\hline Embu-Guaçu & Simples & $\begin{array}{l}\text { Dominio de terrenos vulcano- } \\
\text { sedjumentares, com associaçälo de } \\
\text { nuicleos gnáissico-granitoides, } \\
\text { situados entre zonas de } \\
\text { cisalhaumento } \\
\end{array}$ & Xistos e gntaisses & $\begin{array}{l}\text { Discordantee } \\
\text { concordante }\end{array}$ & $\begin{array}{l}\text { Tabulare } \\
\text { lenticular }\end{array}$ & Quartzo & - Submetricos a dezenas & JPT (1984b) \\
\hline Mogi das Cruzes & Complexo & $\begin{array}{l}\text { Terrenos vulcano-sed imentares e } \\
\text { granitöide }\end{array}$ & Xisios & $\begin{array}{l}\text { Concondante } \\
\text { (?) }\end{array}$ & $\begin{array}{l}\text { Sem dados } \\
\text { disponfveis (s.d.) }\end{array}$ & $\begin{array}{l}\text { Quarizo } \\
\text { Feldspato } \\
\text { Muscovila } \\
\text { Turmal tina }\end{array}$ & s.d. & $\begin{array}{l}\text { IPT (1984b) } \\
\text { Knecht (1950) }\end{array}$ \\
\hline Santa Branca & Simples e recristalizado & $\begin{array}{l}\text { Terrenos vulcanossedimentares e } \\
\text { grapitdides (F́́cies Canlareje), } \\
\text { situado entre possantes zonas de } \\
\text { cisallhamento }\end{array}$ & Xislos e granitoides & Concordante & $\begin{array}{l}\text { Tabular e } \\
\text { lenticular (?) }\end{array}$ & \begin{tabular}{|l|} 
Quirtzo \\
Feldspato \\
Muscovita \\
Turmalina \\
Metais Raros \\
\end{tabular} & - Mélrica & $\mathrm{IPT}(1984 \mathrm{~b})$ \\
\hline Sa]o Luiz do Paraitfnga & $\begin{array}{l}\text { Simples. } \\
\text { recristalizadoe } \\
\text { complexo }\end{array}$ & $\begin{array}{l}\text { Terrenos granitoides e vulcanos- } \\
\text { sedimentares, com zonas de } \\
\text { cisalhamento associadas }\end{array}$ & Xistos e gnaisses & $\begin{array}{l}\text { Discordante } \\
\text { concordante }\end{array}$ & $\begin{array}{l}\text { Tabular e } \\
\text { Ienticular }\end{array}$ & $\begin{array}{l}\text { Quartzo } \\
\text { Feldspato } \\
\text { Muscovita } \\
\text { Turmalina } \\
\text { Gerilo } \\
\text { Metdis Raros }\end{array}$ & - Métrico (1 a 50 metros) & $\begin{array}{l}\text { IPT (1984b) } \\
\text { KNECHT apud } \\
\text { THEMAG (1982) }\end{array}$ \\
\hline Bananal & Simples & $\begin{array}{l}\text { Terrenos guálissico-granilode e } \\
\text { vulcanossedimentares, com zonas } \\
\text { de cisalhamento associadas }\end{array}$ & $\begin{array}{l}\text { Xistos e githisses } \\
\text { milonitizados }\end{array}$ & Discondante & $\begin{array}{l}\text { Tabulare } \\
\text { lenticular }\end{array}$ & $\begin{array}{l}\text { Quartzo } \\
\text { Feldspato } \\
\text { Muscovita } \\
\text { Turmalina } \\
\text { Metais Raros }\end{array}$ & - Méırico (5 \& 10 metros) & $\begin{array}{l}\text { IPT (1983) } \\
\text { IPT (1984i) }\end{array}$ \\
\hline Perus/Guarulhos & $\begin{array}{l}\text { Simples, recristalizado } \\
\text { e complexo }\end{array}$ & $\begin{array}{l}\text { Terrenos graniloides, } \\
\text { gnfíssico-granitoides e } \\
\text { vulcanossedimentares }\end{array}$ & $\begin{array}{l}\text { Xistos, ć́lcio-silicaticats, } \\
\text { gnaisses e gnaisses } \\
\text { milomitizados }\end{array}$ & Discordante & $\begin{array}{l}\text { Owoide, lenticular } \\
\text { e tabular }\end{array}$ & \begin{tabular}{|l|} 
Quartzo \\
Feldspato \\
Muscovita \\
Turmalina \\
Piropo \\
Apalita \\
Metais Raros
\end{tabular} & $\begin{array}{l}\text { - s.d. } \\
\text { Centimétricos alé } \\
\text { dezenas a centenas de } \\
\text { melros }\end{array}$ & $\begin{array}{l}\text { IPT (1984a) } \\
\text { Knecht apud } \\
\text { Hasui (1963) }\end{array}$ \\
\hline Socorto & Recristalizado & $\begin{array}{l}\text { Terrenos gnfissico-graniloides e } \\
\text { allo grau metamorfico, com } \\
\text { zonas de cisalhamento associadas }\end{array}$ & $\begin{array}{l}\text { Gnaisses, gnaisses } \\
\text { milonitizados e } \\
\text { blastomilonitos }\end{array}$ & Discordante & $\begin{array}{l}\text { Tabular, } \\
\text { lenticular } \\
\text { ovoide e irregular }\end{array}$ & $\begin{array}{l}\text { Quartzo } \\
\text { Feldspato } \\
\text { Muscovila } \\
\text { Turmalina }\end{array}$ & $\begin{array}{l}\text { - metricos ( } 5 \text { a } 10 \text { metros) } \\
\text { - dezenas a centenas de } \\
\text { metros }\end{array}$ & IPT (1984a) \\
\hline
\end{tabular}




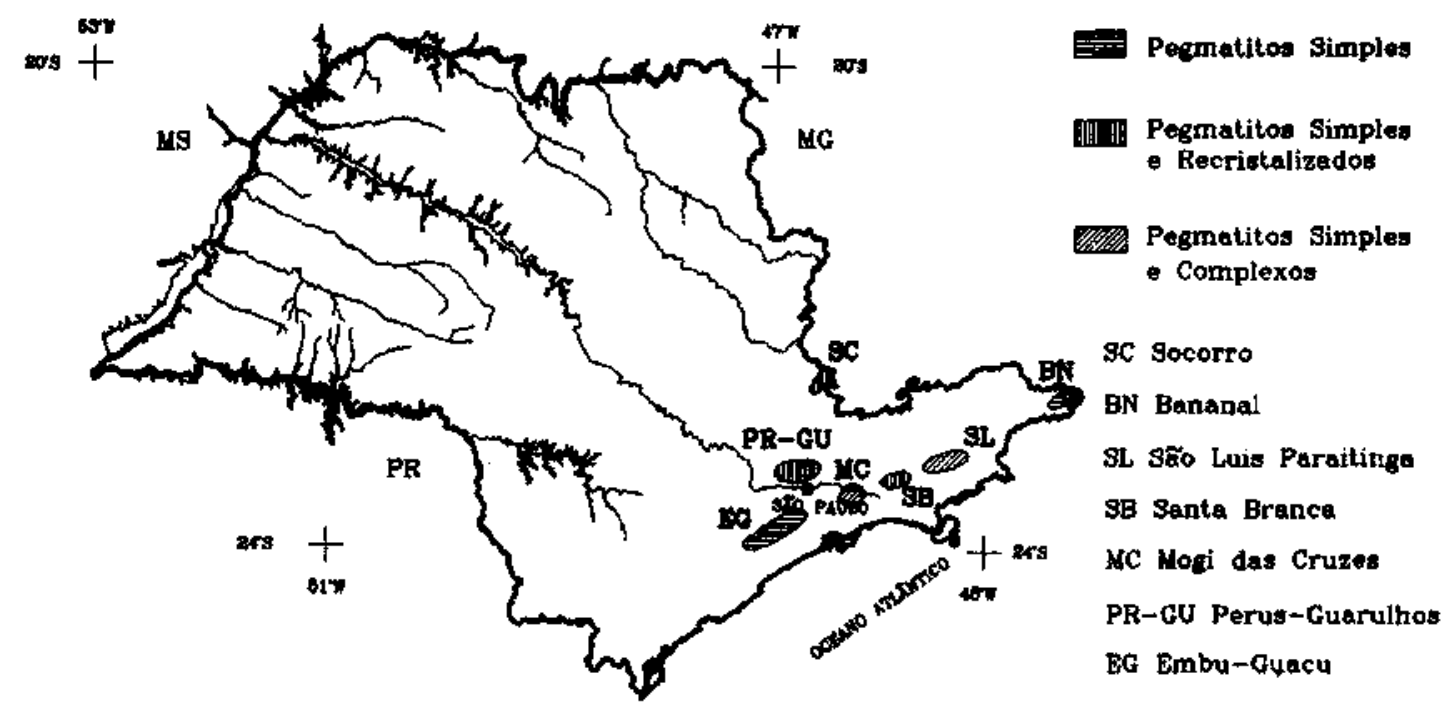

Figura 7 - Áreas com ocorrência concentrada de pegmatitos em São Paulo Figure 7 - Main pegmatitic areas in the State of São Paulo

Terrenos gnáissico-granitóides e de alto grau metamórfico Os terrenos gnáissico-granitóides e de alto grau metamórfico possuem ampla distribuição geográfica no Estado, constituindo praticamente um terço do embasamento pré-cambriano (Fig. 8).

Seqüências de alto grau metamórfico, fácies granulito, constituem núcleos isolados, como os da serras de Itatins, Bertioga, Ubatuba, Monteiro Lobato, Socorro, Divinolândia e Mococa, ou ocorrem em faixas onde coexistem com rochas de grau médio.

Dois segmentos pré-cambrianos são constituídos essencialmente por estas unidades. O mais expressivo e contínuo refere-se à porção setentrional do embasamento paulista, sendo representado pelos complexos Varginha e Amparo, como conceituados por IPT (1981a). A segunda faixa corresponde ao Complexo Costeiro (IPT op. c/V.), que constitui cinturão localizado ao sul da Falha de Cubatão.

A porção do embasamento intermediária entre estes dois domínios se apresenta recoberta por supracrustais vulcanosedimentares e metassedimentares, onde afloram mais esparsamente núcleos do substrato gnáissico-granitóide e rochas granulíticas (i.e. Monteiro Lobato). Mais recentemente, trabalhos de mapeamento de maior detalhe têm revelado que parte da fácies granitóide Cantareira de Hasui et al.

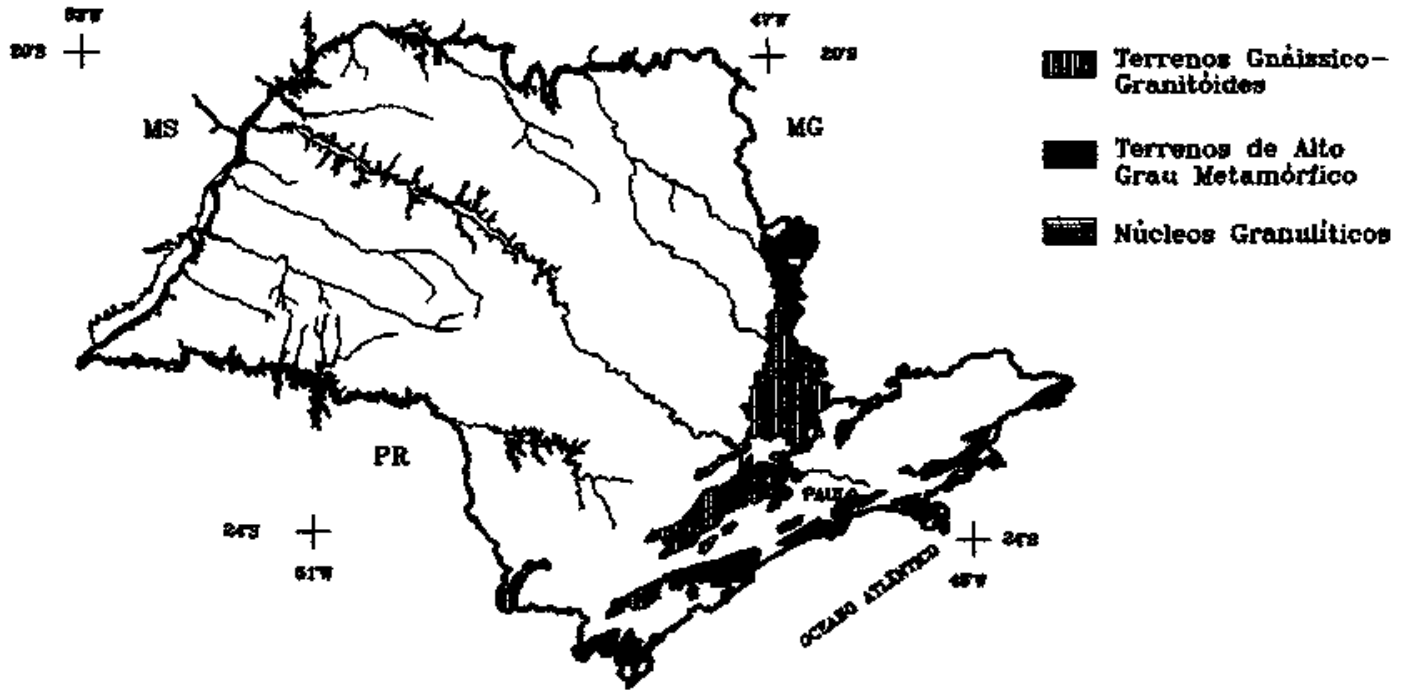

Figura 8 - Distribuição dos terrenos gnáissico-granitóides e de alto grau metamórfico em São Paulo Figure 8 - Gnaissic-granitic and high grade metamorphic terrains in São Paulo State 
(1978), a exemplo dos maciços Três Córregos e Morro Agudo, no vale do rio Ribeira, se constitui, na verdade, em segmentos gnáissico-granitóides. Isto deve se repetir em terrenos similares da porção nordeste do embasamento e mesmo em certos ambientes supracrustais (i.e. Complexo Embu, como definido em IPT 1981a).

Uma vez que os terrenos considerados são portadores ordinários de minerais dos ETR, em particular a monazita-(Ce), seu potencial metalogenético está vinculado à sua suposta capacidade como áreas-fonte para concentrações detríticas secundárias. Desta forma, a grande extensão geográfica dos terrenos gnáissico-granitóides e de alto grau metamórfico.verificada no Estado, abre perspectivas favoráveis ao aporte significativo de minerais dos ETR para diversos sítios deposicionais. Por outro lado, depósitos primários fílonianos podem ocorrer relacionados às extensas zonas de cisalhamento que cortam estas seqüências.

Fosforitos Freqüentemente os ETR se associam com rochas fosfatadas (Laznicka 1985). Tratam-se, no entanto, de concentrações subeconômicas, fazendo com que seu aproveitamento seja possível apenas como subproduto do beneficiamento do próprio fosfato.

Muito embora não sejam conhecidos fosforitos em São Paulo, ocorrem unidades litoestratigráficas sedimentares compatíveis com sistemas mineralizantes fosfáticos (Fig. 9 e Quadro 7).

Neste caso, as melhores perspectivas de mineralizações dos ETR se relacionam com as seqüências metassedimentares do Proterozóico Superior: Grupo Itaiacoca, Subgrupo Lageado e Grupo São Roque (parte carbonática). Os parâmetros geológicos que justificam esta suposição são: a) a paleogeografia dessas seqüências, já que constituem bacias marinhas com ambientes plataformais bem desenvolvidos, provavelmente conectados a condições oceânicas mais francas, com possível acesso de correntes marinhas profundas (upwelling currents). Poderiam corresponder, desta forma, a sítios para aporte e acúmulo de sedimentos fosfáticos; b) a presença de expressivos pacotes carbonáticos, indicativos de condições paleoclimática e paleolatitudinais favoráveis à proliferação da biomassa marinha;

c) o regime tectônico relativamente ameno registrado nestas unidades, que possibilitaria a preservação dos eventuais horizontes bioquímicos fosfáticos e de guias prospectivos faciológicos e estratigráficos.

Evaporitos Dentro do cenário geológico do Estado de São Paulo, ocorrem algumas seqüências sedimentares que registram sítios deposicionais condizentes com condições climáticas evaporíticas (Fig. 9).

A existência de mineralizações dos ETR nestes ambientes, no entanto, é reduzida e parece se restringir a ocorrências em lagos evaporíticos alimentados por fonte vulcânica alcalina (Laznicka 1985).

No caso dos terrenos do Estado, é praticamente inexistente a associação das faixas compatíveis com depósitos de evaporitos e áreas-fonte com episódios vulcânicos ou mesmo litotipos magmáticos enriquecidos em ETR, o que inibe sobremaneira a possibilidade de mineralizações destes elementos nos metalotectos considerados.

Mesmo neste contexto desfavorável, podem-se relacionar especulativamente o Grupo Bauru e as bacias do Sistema de Rifts da Serra do Mar como portadores de fácies evaporíticas que melhor reúnem os condicionantes básicos deste sistema mineralizante, a saber: calcretes, foscretes, argilas autígenas (esmectita e paligorskita), e atividades vulcânicas, embora discretas (Cabral Júnior 1991).

\section{AFERIÇÃO DOS MODELOS METALOGENÉTICOS}

Trabalhos de campo expeditos contribuíram para aperfeiçoamento da análise exploratória. Esta atividade enfocou algumas áreas representativas das ambiências apontadas como potenciais para mineralizações dos ETR ou possuidoras de mineralizações já conhecidas destes elementos.

Como representantes de maciços alcalinos, foram visitados os complexos de Poços de Caldas e Ipanema. Depósitos tipo plácer foram observados na bacia de Taubaté, região de Tremembé-São José dos Campos e, mais detalhadamente,

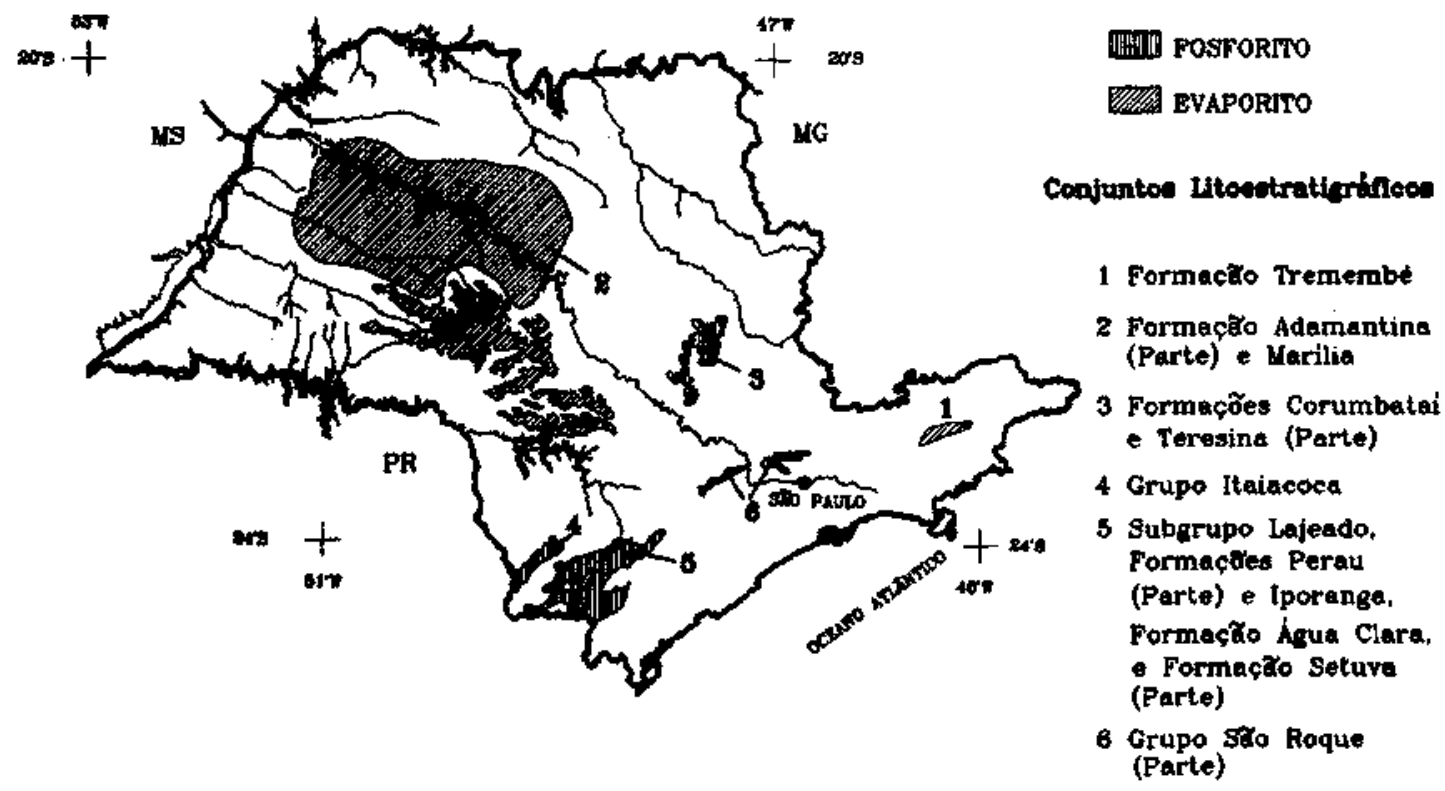

Figura 9-Unidades compativeis com a ocorrência de depósitos defosforito e evaporito em São Paulo

Figure 9 - Potential areas for phosphorite and evaporite deposits in the State of São Paulo 


\begin{tabular}{|c|c|c|c|c|c|c|c|c|c|}
\hline $\begin{array}{c}\text { Unddades } \\
\text { Litoesdratigrathicas } \\
\end{array}$ & Idade & Associaçón Lític: & Horizontes Quimicos & $\begin{array}{l}\text { Deformapao } \\
\text { Tectontea }\end{array}$ & $\begin{array}{c}\text { Grau } \\
\text { Metamörfico }\end{array}$ & $\begin{array}{c}\text { Ambiente } \\
\text { Deposkional }\end{array}$ & $\begin{array}{l}\text { Ambiente } \\
\text { Tectónico }\end{array}$ & Ocorrencias & $\begin{array}{l}\text { Bäbljografta } \\
\text { Consultada }\end{array}$ \\
\hline Grupo Ituideces & PMS & 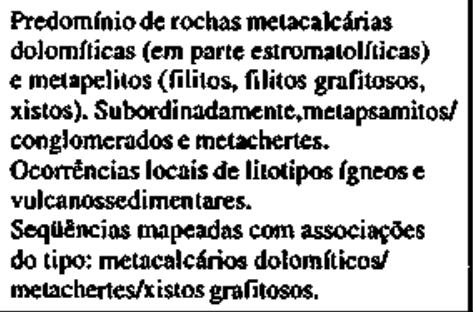 & 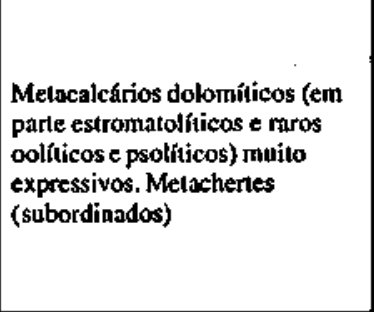 & $\begin{array}{l}\text { Fraca (empilhamento } \\
\text { estratigrafico original } \\
\text { preservado em kentes } \\
\text { tectónicas }\end{array}$ & Baix o a incipiente & Litorfinto/planaformal & Retroaroo(?) & $x$ & IPT (1988b) \\
\hline $\begin{array}{l}\text { Formapäo } \\
\text { Agea Clara }\end{array}$ & PMI & $\begin{array}{l}\text { Predominio de mehas cartionálicas } \\
\text { impuras e cálciossilicáticas, alterinadas } \\
\text { com metapelitos. Ocontem tarnbém } \\
\text { litotipos vulcánicos (anlibólio xistos, } \\
\text { metachertes, metatufos). }\end{array}$ & $\begin{array}{l}\text { Conjuntos mistos, de grande } \\
\text { porte, de tochas cálciossili- } \\
\text { ćticas, carbonalos, xistos } 6 \\
\text { mánmores }\end{array}$ & Forle & Medio a alto & $\begin{array}{l}\text { Plataformaly } \\
\text { marinho profundo }\end{array}$ & Relraarco(n) & & $\begin{array}{l}\text { IPT (1988b) } \\
\text { Soares (1987) }\end{array}$ \\
\hline Subgrupo Lajeado & PMS & 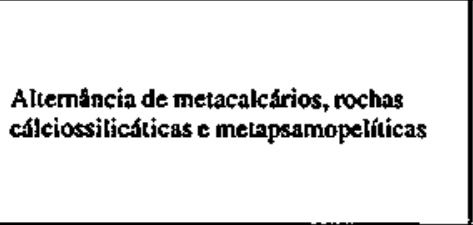 & 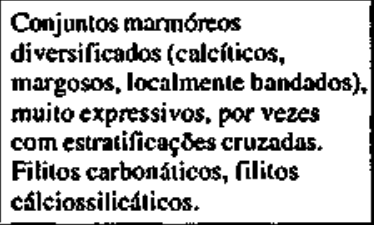 & Fraca & Baixo & Litortineo/plataformal & Retroarco(?) & & $\begin{array}{l}\text { IPT (1988b) } \\
\text { Soares (1987) }\end{array}$ \\
\hline Formaçāo Perau & PMI(?) & 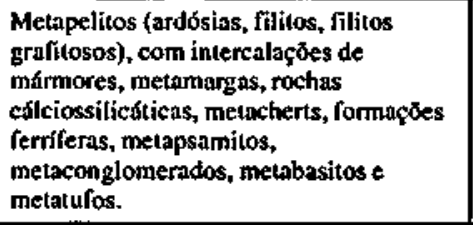 & 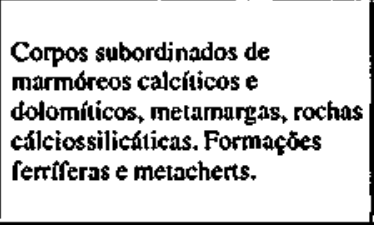 & Forle & Baixo & Plataformal// & Retroarco(?) & & $\begin{array}{l}\text { IPT (1988b) } \\
\text { Soares (1987) }\end{array}$ \\
\hline Fortnaçẵo Setuva & PM! & $\begin{array}{l}\text { Xistos e filitos (por vezes gralitosos), } \\
\text { metapelitos, com intercalap̧os } \\
\text { subordinadas de metabasitos, gondilos e } \\
\text { gnaisses, Conjuntos marmoreose } \\
\text { cdlciossilicáticos com intercalapoes de } \\
\text { clorita xistos e quartzilos. }\end{array}$ & $\begin{array}{l}\text { Conjuntos matmóreos } \\
\text { (dolomiticos) expressivos com } \\
\text { intercalaçós cállciossilicáticas }\end{array}$ & Forte & Baixo & $\begin{array}{l}\text { Plataformal/ } \\
\text { marisho proflundo }\end{array}$ & Retrocarco(?) & & $\begin{array}{l}\text { IPT (1988b) } \\
\text { Soares (1987) }\end{array}$ \\
\hline Grupo Sāo Roque & PS & 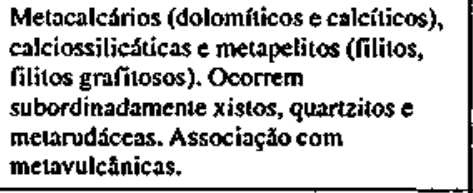 & $\begin{array}{l}\text { Corpos expressivos de } \\
\text { metacalcários (dolomíticos e } \\
\text { calciticos) Jocatlmente } \\
\text { estromatolíticos. }\end{array}$ & Fraca & Baixo & Litorăneo/platarormal & Retrocarco(?) & & IPT (1981a) \\
\hline $\begin{array}{l}\text { Formaçtes } \\
\text { Corumbatini e } \\
\text { Teresina }\end{array}$ & $\mathbf{P}$ & $\begin{array}{l}\text { Intercialaçdes de folhel hos, sillitos, } \\
\text { arenicos fjnos e calcários. }\end{array}$ & $\begin{array}{l}\text { Camadas e lentes subordinadas } \\
\text { de inargas e calcítios } \\
\text { biodetrificos microcristalinos, } \\
\text { com niveis oolficos, ocorrendo } \\
\text { localmente estruturas } \\
\text { estromatolf́icas. }\end{array}$ & Incipiente & Ausenle & $\begin{array}{l}\text { Costeiro raso (plarlcie } \\
\text { de mare) e } \\
\text { plataformal, sem } \\
\text { conexao efetiva corn } \\
\text { mar abterto }\end{array}$ & Inuracratonica & & $\begin{array}{c}\text { IPT (1981b) } \\
\text { Cabral Jr. } \\
\text { (1991) } \\
\text { Soares (1987) }\end{array}$ \\
\hline
\end{tabular}


no litoral sul paulista, no trecho entre Itanhaém e a Ilha do Cardoso. No que se refere a maciços granitóides, efetuou-se amostragem de rochas e sedimentos de corrente do Granito Mandira, no baixo vale do rio Ribeira. Áreas e depósitos sedimentares relacionados a pegmatites foram estudados em Perus e Mogi das Cruzes. O modelo fosforito foi verificado por perfis geológicos feitos no Grupo Itaiacoca, na região de Itapeva.

Não foram observadas mineralizações primárias em nenhuma das áreas visitadas. O Quadro 8, por sua vez, resume os resultados analíticos, mineralógicos e químicos decorrentes da amostragem, naqueles locais, de alguns horizontes sedimentares detríticos. Verifica-se que estas amostras apresentam massa reduzida de concentrados de minerais pesados (CMPs), ainda mais se comparadas com conteúdos equivalentes em depósitos conhecidos do conjunto ilmenitarutilo-zircão-monazita-(Ce) (IRZM), nos quais o conteúdo de CMP gira em torno dos 90 a $100 \mathrm{~kg} / \mathrm{m}^{3}$, podendo atingir extremos anômalos de até $1000 \mathrm{~kg} / \mathrm{m}^{3}$.

Em termos mineralógicos, predomina amplamente a ilmenita, alternando-se, em seguida, como mais abundantes, zircão e monazita-(Ce). A presença de rutilo é bastante reduzida, muito embora se deva considerar a presença quase constante de representantes isomorfos do mineral na fração magnética do CMP, que foram classificados indistintamente como ilmenita.

Verificam-se, por outro lado, diferenças muito pronunciadas entre os conteúdos de monazita-(Ce) indicados por cálculos estequiométricos, derivados das análises químicas e os teores estabelecidos pelas análises mineralógicas. De fato, sendo a monazita-(Ce) o único mineral dos ETR presente, já que baixos teores de xenotímio-(Y) foram observados apenas na amostra EM-01, os percentuais de óxidos de terras-raras (OTR) quimicamente dosados nas amostras MC-01, MC-01A, LS-06 e EM-01 conferem a estas, respectivamente, teores de monazita-(Ce) da ordem de $2,3 \mathrm{~kg} / \mathrm{m}^{3}$, $4,7 \mathrm{~kg} / \mathrm{m}^{3}, 12,2 \mathrm{~kg} / \mathrm{m}^{3} \mathrm{e} 13,9 \mathrm{~kg} / \mathrm{m}^{3}$, bem maiores que os 0,23 $\mathrm{kg} / \mathrm{m}^{3}, 0,17 \mathrm{~kg} / \mathrm{m}^{3}, 6,7 \mathrm{~kg} / \mathrm{m}^{3}$ e $7,9 \mathrm{~kg} / \mathrm{m}^{3}$ registrados pela análise mineralógica. Considerando que eventuais imprecisões analíticas não justificariam discrepâncias de tal ordem de grandeza, pode-se supor que o conteúdo de monazita(Ce) esteja subavaliado eticamente.

E marcante a maior presença dos ETR nos sedimentos continentais das Bacias de Taubaté e São Paulo e nos sedimentos costeiros da Formação Cananéia. Quanto aos representantes da Bacia de São Paulo, embora sejam muito reduzidos os conteúdos de pesados, verificam-se nos concentrados teores elevados de minerais industriais (turmalina, estaurolita e cianita) de densidade intermediária. Estes teores passam a ser mais significativos ao levar-se em conta que boa parte daqueles minerais certamente foi descartada durante o processo de concentração das amostras.

\section{POTENCIAL DO ESTADO DE SÃO PAULO PARA OS}

ETR Para maior precisão dos termos utilizados na análise da potencialidade do Estado de São Paulo quanto aos ETR, recorre-se aqui à terminologia considerada por Machado (1989) para designação de depósitos minerais não descobertos. Este autor classifica depósitos não descobertos como hipotéticos ou especulativos ante a maior ou menor expectativa quanto à sua existência real. A partir do mesmo critério, analisou-se o Estado com base em seu potencial hipotético e especulativo. A estes conceitos, associou-se graduação qualitativa de potencialidade (maior, intermediária, menor), comparando-se a natureza dos vários terrenos do Estado com a tipologia dos depósitos dos ETR.

As Figuras 10 e 11 resumem o tipo de potencialidade atribuída aos terrenos paulistas. Nestas estão demarcadas as áreas relativas a metalotectos específicos e, no caso de representantes intrusivos, faixas circunvizinhas, balizadas por raios de 5 a $10 \mathrm{~km}$, abrangentes de eventuais manifestações periféricas correlatas e espalhamento dos produtos sedimentares detríticos associados.

As intrusivas alcalinas, os terrenos mais compatíveis com mineralizações do tipo placer, as intrusivas granitóides diferenciadas e as faixas com ocorrência concentrada de pegmatitos foram considerados possuidores de potencialidade hipotética. Ao mesmo tempo, os terrenos gnáissicogranitóides e de alto grau metamórfico, as faixas capazes de abrigar depósitos de natureza fosforítica ou evaporítica e parte do registro sedimentar detrítico fanerozóico estadual foram considerados com potencial apenas especulativo.

$\mathrm{O}$ fato das alcalinas não registrarem, na maioria dos casos, a presença de mineralizações dos ETR, concorre decisivamente para a diminuição da potencialidade destes metalotectos. Para isto contribui também a existência de barreiras tecnológicas à instalação de linhas de beneficiamento das mineralizações secundárias (manto de intemperismo) relacionadas àqueles complexos, seguramente as mais comuns e importantes nestes terrenos. Este quadro negativo, no entanto, pode a qualquer tempo sofrer alterações, à medida que avance o conhecimento geológico sobre as unidades alcalinas já mapeadas, o que estará subordinado aos interesses mineiros das empresas que as mantêm sob requerimento de pesquisa ou decreto de lavra. Outras possibilidades para aumento do significado econômico destas unidades seria a descoberta de novos conjuntos mineralizados e o avanço das técnicas de tratamento mineral das concentrações residuais dos ETR, próprias destes ambientes.

Considerando-se as características dos demais metalotectos com potencialidade hipotética, assumem maior significado as concentrações porventura associadas a pláceres, particularmente nas áreas sedimentares detríticas posicionadas na planície costeira (trecho Itanhaém-Iguape-Cananéia) e nas seqüências areno-conglomeráticas fluviais das bacias de Taubaté e São Paulo. Menos importante, porém digno de registro, é o potencial para depósitos deste tipo relacionado aos aluviões quaternários de áreas com pegmatitos, granitóides especializados e núcleos granulíticos dos terrenos de alto grau metamórfico.

Deve ser observado que a parte sul da planície costeira (planícies de Itanhaém e Iguape-Cananéia) possui trato sedimentar comparável, guardadas as devidas proporções, aos sistemas mineralizantes praiais brasileiros que se estendem da costa fluminense ao sul baiano. Há registro de ciclos sedimentares costeiros bem desenvolvidos, relações com áreas-fonte promissoras (faixas de alto grau metamórfico, granitóides anorogênicos e alguns complexos alcalinos), e um possível pré-concentrador representado pela Formação Pariquera-Açu.

De fato, trabalhos da CPRM (1975) apontam a existência de depósitos portadores de monazita-(Ce) na ponta da Juréia e, menos expressivos, na Ilha do Cardoso (Quadro 9).

Por sua vez, entretanto, Tessler et al.(1985) apresentam resultados pouco promissores em relação à presença de minerais pesados (Quadro 10) naquele trecho.

Segundo estes últimos autores, também os sedimentos superficiais da área plataforma!, instalada até $50 \mathrm{~m}$ de profundidade, não apresentam depósitos econômicos de pesados, sobretudo de maior porte, pela inexistência de mecanismos de transporte e deposição adequados. Não foram amostrados, no entanto, sedimentos mais profundos da seqüência sedimentar submersa. Na região emersa foram analisadas a Formação Cananéia e as fácies praiais atuais. Para a primeira unidade, apenas $5 \%$ das amostras tomadas apresentam concentrações acima do cut-off por eles considerado ( $5 \%$ de pesados na amostra total).

As aferições de campo feitas no âmbito do presente estudo se coadunam melhor com os dados da CPRM (op. cit.). 


\begin{tabular}{|c|c|c|c|c|c|c|c|c|c|c|c|c|c|c|}
\hline \multirow{2}{*}{ Amostro } & \multirow{2}{*}{$\begin{array}{l}\text { - Local } \\
\text { - Modo de Ocorretncia }\end{array}$} & \multirow{2}{*}{$\begin{array}{c}\begin{array}{c}\text { Volume } \\
\text { Amostrado } \\
\left(m^{3}\right)\end{array} \\
\end{array}$} & \multirow{2}{*}{$\begin{array}{c}\text { Messa } \\
\text { Concentrado } \\
\text { (g) } \\
\end{array}$} & \multirow{2}{*}{$\begin{array}{l}\text { CMP } \\
\left(g / m^{3}\right)\end{array}$} & \multicolumn{6}{|c|}{ Minerais Pesados (kg/m) } & \multicolumn{4}{|c|}{ Análises Quimicas dos Pesados (\%) } \\
\hline & & & & & Ilmenita & Rutilo & Zires̃o & Monazita & IRZM & Outros & OTR & $\mathbf{Y}_{2} \mathbf{O}$, & $\mathrm{ZrO}_{2}$ & $\mathrm{THO}_{2}$ \\
\hline PR-01 & 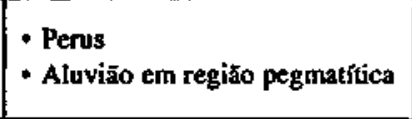 & 0,015 & 0,4910 & 32,7 & 1,7 & $<0,01$ & 0,12 & 0,00 & 1,82 & $\begin{array}{c}\text { Turmalina } \\
\text { Estaurolita } \\
\text { cianita }\end{array}$ & 0,05 & $>0,01$ & 0,18 & 2,0 \\
\hline MC-01 & $\begin{array}{l}\text { - Mogi das Cruzes } \\
\text { - Aluvião na Bacia Sžo Paulo }\end{array}$ & 0,010 & 0,1134 & 11,3 & 2,4 & 0,01 & 0,23 & 0,23 & 3,04 & $\begin{array}{c}\text { Turmalina } \\
\text { Estaurolita } \\
\text { cianita }\end{array}$ & 3,28 & 0,74 & 2.5 & 21,1 \\
\hline MC-01A & $\begin{array}{l}\text { - Mogi das Cruzes } \\
\text { - Aluvião na Bacia São Paulo }\end{array}$ & 0,020 & 0,0713 & 3,6 & 1,4 & 0,01 & 0,09 & 0,17 & 1,67 & $\begin{array}{c}\text { Turmalina } \\
\text { Estaurolita } \\
\text { cianita }\end{array}$ & 3,65 & 0,83 & 3,3 & 32,2 \\
\hline IP-01 & $\begin{array}{l}\text { - Ipanema } \\
\text { - Aluvizo sobre a alcalina đe } \\
\text { Ipanema }\end{array}$ & 0,015 & 0,1927 & 12,8 & 4,4 & 0,02 & 0,16 & $<0,01$ & 4,58 & Apatita & 0,06 & $<0,01$ & 1,5 & 9,9 \\
\hline LS-01 & $\begin{array}{l}\text { - Rod. Bigua-iguapé } \\
\text { - Arenitos (Fm. Pariquiera-Açu) }\end{array}$ & 0,015 & 0,0091 & 0,6 & 0,4 & $<0,01$ & 0,07 & 0,02 & 0,49 & - & 1,91 & 0,08 & 16,4 & 41,1 \\
\hline LS-02 & $\begin{array}{l}\text { - Barra de Icapara } \\
\text { - Terraço praial } \\
\end{array}$ & 0,015 & 0,0907 & 6,0 & 4,9 & 0,08 & 0,86 & 0,11 & 5,95 & - & 1,12 & 0,11 & 17,1 & 41,8 \\
\hline LS-03 & $\begin{array}{l}\text { - Barra de Icapara } \\
\text { - Praia Atual } \\
\end{array}$ & 0,015 & 0,9356 & 35,7 & 27,7 & 0,12 & 4,43 & 0,57 & 32,82 & - & 1,08 & 0,13 & 14,2 & 42,5 \\
\hline LS-04 & $\begin{array}{l}\text { - Ilha do Cardoso } \\
\text { - Terraço praial } \\
\end{array}$ & 0,015 & 1,3537 & 90,2 & 71,2 & 0,54 & 13,24 & 0,40 & 85,38 & - & 0,51 & 0,04 & 15,1 & 42,8 \\
\hline LS-05 & $\begin{array}{l}\text { - Itapitangui } \\
\text { - Aluviāo sobre o Granito } \\
\text { Mandira }\end{array}$ & 0,015 & 0,0988 & 6,6 & 6,1 & $<0,01$ & 0,28 & 0,00 & 6,38 & - & 0,09 & 0,05 & 5,2 & 48,3 \\
\hline LS-06 & \begin{tabular}{|l} 
- Itapitangui \\
- Fm. Cananéia \\
\end{tabular} & 0,015 & 0,8239 & 54,9 & 41,4 & 0,16 & 5,00 & 6.7 & 53.27 & - & 3,30 & 0,27 & 9,8 & 44,7 \\
\hline EM-01 & $\begin{array}{l}\text { - Eugênio de Mello } \\
\text { - Conglomerado } \\
\text { (Frn. Pindamonhangaba) }\end{array}$ & 0,015 & 0,6441 & 42,9 & 23,50 & 0,20 & 6,00 & 7,9 & 37,60 & - & 16,16 & 1,00 & 8,0 & 32,3 \\
\hline
\end{tabular}




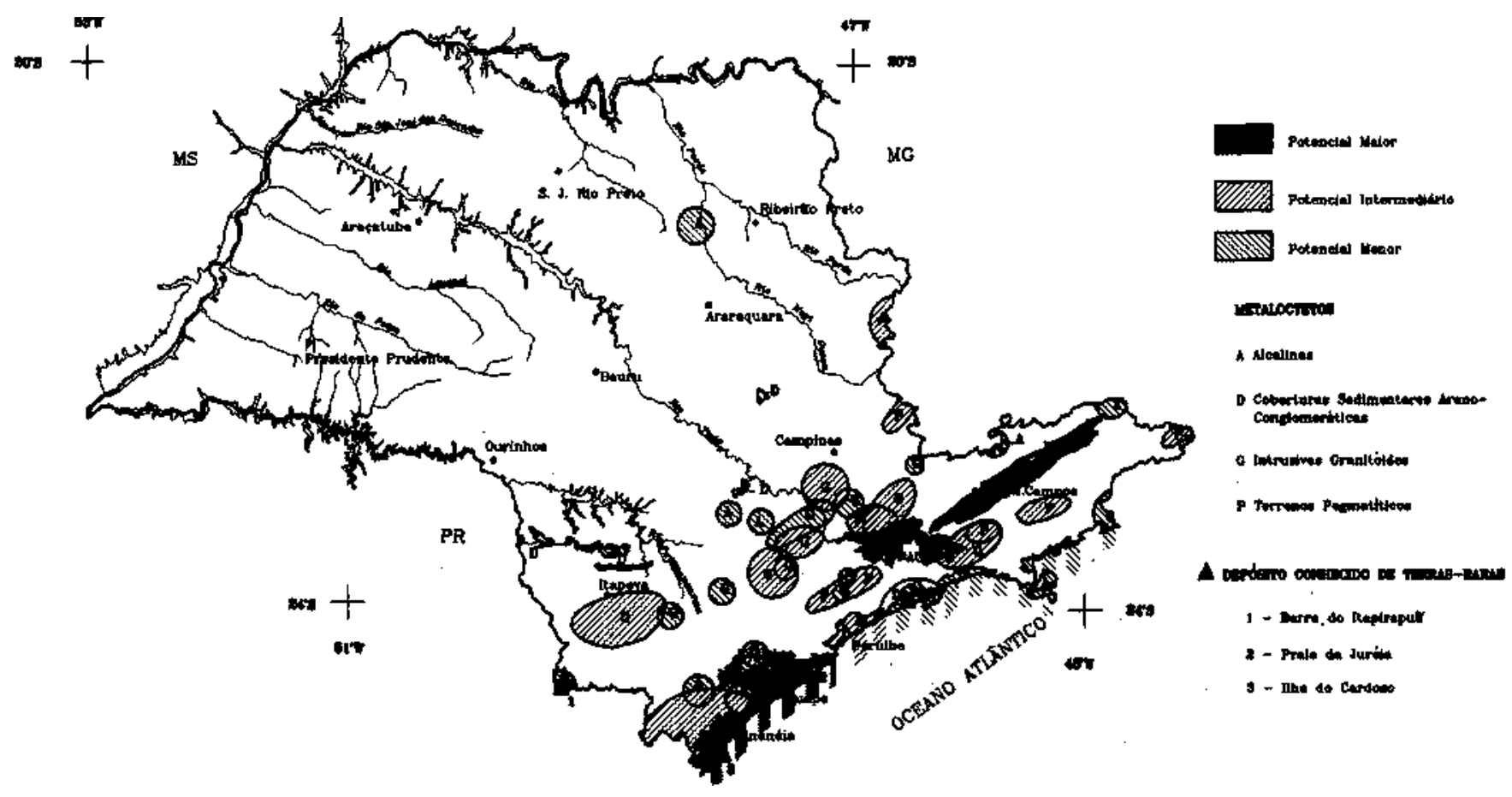

Figura 10 -Áreas do Estado de São Paulo com potencial hipotético para depósitos de terras-raras Figure 10 - Hypotetic potential areas for REE deposits in the State of São Paulo

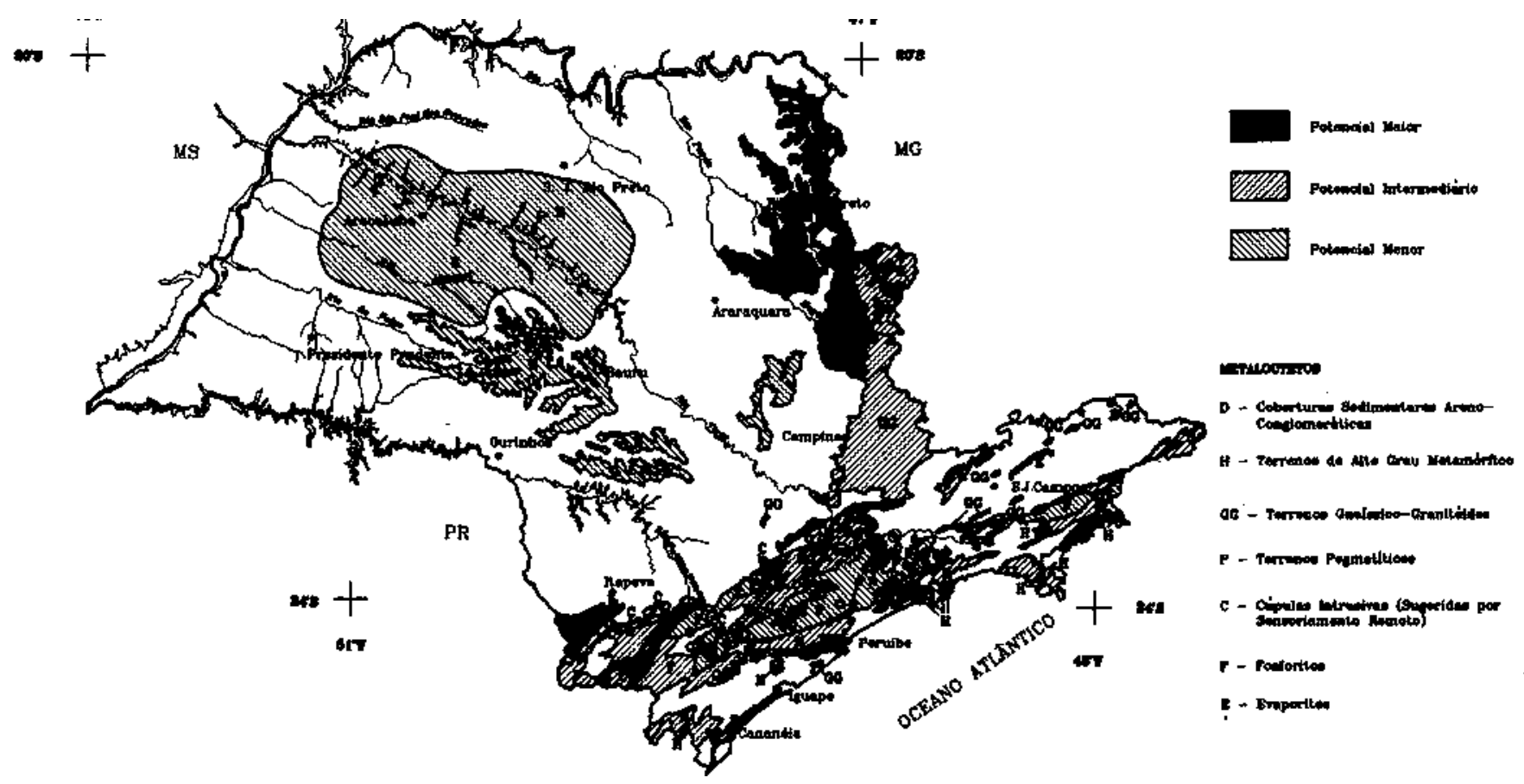

Figura 11 -Áreas do Estado de São Paulo com potencial especulativo para depósitos de terras-raras

Figure 11 - Speculative potential áreas for REE deposits in the State of São Paulo

Além disto, as ocorrências de monazita-(Ce), descobertas em faixas mais interiores continentais (amostra LS-06, no Quadro 8), ampliam o horizonte geográfico mais favorável à busca de novos depósitos.

Ponderados todos os aspectos anteriores, seriam objetos de maior interesse as armadilhas relacionadas a canais tipo inlet e washover, pontos de convergência de correntes litorâneas (Tessler et al 1985) e altos e paleoaltos do embasamento (esporões).
De qualquer modo, as possibilidades para a existência de mineralizações dos ETR, nesta faixa, forçosamente se limitam à escala dos depósitos de porte muito pequeno a pequeno.

Obstáculo adicional à exploração mineral deve-se ao fato de boa parte da área costeira inserir-se em faixas de conservação ambiental.

Em relação à parte imersa da planície costeira, considerados os custos envolvidos na pesquisa mineral off-shore, a 
Quadro 9 -Depósitos de minerais pesados nas praias do Litoral Sul do Estado de São Paulo (CPRM 1975). Chart 9 - Heavy mineral placer deposits in the southern coast of the State of São Paulo.

\begin{tabular}{|c|c|c|c|c|c|c|c|}
\hline \multirow[b]{2}{*}{ LOCAL } & \multirow{2}{*}{$\begin{array}{l}\text { CONTEUDO DE } \\
\text { PESADOS (\%) }\end{array}$} & \multicolumn{4}{|c|}{ COMPOSIÇÃO DE PESADOS } & \multirow{2}{*}{\multicolumn{2}{|c|}{$\begin{array}{c}\text { TONELAGEM } \\
\text { (x 1.000) } \\
\text { toneladas) }\end{array}$}} \\
\hline & & ILMENITA & RUTILO & ZIRCĀO & MONAZITA & & \\
\hline PRAIA DA JURÉIA & 20 & 40 & 0,8 & 3,0 & 3,0 & 20,9 & 1,5 \\
\hline PRAIA DE FORA & 2 & 50 & 0,6 & 1,6 & 3,6 & 5,4 & 0,4 \\
\hline PRAIA DAS PEDRAS & 23 & 63 & 1,1 & $6, \overline{2}$ & 1,2 & 6,2 & 0,1 \\
\hline
\end{tabular}

exploração deste ambiente parece se justificar apenas se forem descobertas novas e significativas mineralizações na área emersa.

Já as bacias de Taubaté e São Paulo contam com ciclos fluviais bem desenvolvidos, formados sob a influência de clima quente e úmido (Riccomini 1989). No que se refere aos ETR, estas bacias se relacionam com áreas-fonte supostamente enriquecidas, representadas por terrenos gnáissicogranitóides e pegmatíticos (i.e. região de Mogi das Cruzes). Quanto a isto, apesar do caráter preliminar, expedito e apenas aferidor dos trabalhos de campo, detectou-se conteúdo dos ETR importante e representativo em Eugênio de Melo, região de São José dos Campos (Quadro 8), relacionado com as seqüências arenosas do topo da Bacia de Taubaté (Formação Pindamonhangaba). Neste caso, o horizonte amostrado revelou massa de monazita-(Ce) em torno de 14 $\mathrm{kg} / \mathrm{m}^{3}$, estimada a partir do teor químico de $16 \%$ de OTR no concentrado de bateia obtido. Foram igualmente registrados teores de $42,9 \mathrm{~kg} / \mathrm{m}^{3}$ de CMP, $23,5 \mathrm{~kg} / \mathrm{m}^{3}$ de ilmenita e 6,0 $\mathrm{kg} / \mathrm{m}^{3}$ de zircão. Para comparação, sem que sejam considerados os demais aspectos de economicidade envolvidos, no rio Sapucaí, Minas Gerais, foi estabelecido plano piloto de lavra e beneficiamento para os aluviões locais a partir de teores médios de $26,4 \mathrm{~kg} / \mathrm{m}^{3}$ de CMP, $16,7 \mathrm{~kg} / \mathrm{m}^{3}$ de ilmenita, $1,4 \mathrm{~kg} / \mathrm{m}^{3}$ de monazita-(Ce) e $4,3 \mathrm{~kg} / \mathrm{m}^{3}$ de zircão (SAMITRI 1984).

Mais uma vez, no entanto, os metalotectos potenciais, representados por conglomerados e arenitos conglomeráticos fluviais, tendem a possuir dimensões reduzidas e pouco contínuas. Pode-se especular a existência de depósitos individuais de muito pequeno porte, com teores médios oil eventualmente altos (volumes a partir de $10.000 \mathrm{~m}^{3} \mathrm{e}$ teores de até $14 \mathrm{~kg}$ de monazita- $\left.(\mathrm{Ce}) / \mathrm{m}^{3}\right)$. Estes depósitos estariam relacionados com níveis concentradores, de espessura métrica a submétrica, que poderiam possibilitar ocorrências da ordem de centenas de toneladas de monazita-(Ce) contida.

Quadro 10 - Distribuição de minerais pesados na região costeira de Iguape-Cananéia (segundo Tessler 1985) Chart 10 - Heavy mineral distribution in the Iguape-Cananéia coastal plain

\begin{tabular}{|c|c|c|c|c|}
\hline \multirow[t]{2}{*}{ Untdndes } & \multirow{2}{*}{$\begin{array}{l}\text { Número de } \\
\text { Amostras } \\
\text { Analisadas }\end{array}$} & \multicolumn{3}{|c|}{$\begin{array}{l}\text { Conteúdo de Minerais } \\
\text { Pesados ( } \% \text { em Peso) }\end{array}$} \\
\hline & & Máximo & Mínimo & Medio \\
\hline Fm. Cananeia & 120 & 19,80 & 0,02 & 1,14 \\
\hline $\begin{array}{l}\text { Plataforma rasa } \\
\text { (0-10 m de } \\
\text { profundidade) }\end{array}$ & \multirow[t]{2}{*}{133} & 4,93 & 0,02 & - \\
\hline $\begin{array}{l}\text { Plataforma } \\
10-50 \mathrm{~m}\end{array}$ & & 1.61 & 0,02 & - \\
\hline Praja Atual & 47 & 18,55 & 0,07 & - \\
\hline
\end{tabular}

Pelas características inerentes à natureza e à própria situação geográfica das unidades consideradas, há uma série de outros aspectos a serem levados em conta. Quanto a isto, verifica-se que a potencialidade da existência de depósitos sedimentares detríticos continentais dos ETR se reveste, em princípio, de caráter relativamente alternativo. De fato, em termos mundiais a produção se mostra afeita a depósitos detríticos concentrados em faixas costeiras. No Brasil, é esporádico o registro da exploração de áreas continentais. Mais ainda, neste caso nota-se a existência de aspectos impeditivos à lavra, na forma do freqüente capeamento estéril dos horizontes de interesse, e a densa ocupação dessas áreas, característica extremada no caso da Bacia São Paulo. Por outro lado, trata-se de faixa intensamente explotada para argila e, principalmente, areia para construção civil, o que abre perspectiva para aproveitamento da monazita-(Ce) como sub-produto de empreendimentos mineiros já instalados. Além disto, a constatação da associação IRZM com minerais industriais (turmalina, estaurolita e cianita), pelo menos nas áreas amostradas em Mogi das Cruzes e São José dos Campos, abre perspectivas para explotação destes minerais como sub-produtos das lavras locais.

Especificamente quanto ao ítrio, o potencial estadual parece bem mais restrito. Pela própria natureza da mineralização de xenotímio-(Y), seu principal mineral-minério, e pelos dados disponíveis quanto aos pesados no registro sedimentar costeiro e continental, pode ser esperado que o elemento tenha seu significado econômico subordinado à existência de mineralizações de cúpulas granitóides das quais decorram depósitos secundários detríticos. Mesmo nestes casos, aquele mineral seria recuperado como coproduto ou sub-produto da lavra de conteúdos de cassiterita, volframita e associados. Possibilidade talvez mais remota advém do virtual beneficiamento de conteúdos elevados de ítrio existentes em depósitos de monazita-(Ce). Note-se, quanto a isto, que o conteúdo monazítico amostrado em Eugênio de Melo parece ser o principal responsável pelo teor de $1 \%$ de $\mathrm{Y}_{2} \mathrm{O}_{3}$ dosado naquele material.

CONSIDERAÇÕES FINAIS No Brasil, muito embora repetido o quadro mundial relativo à distribuição das reservas conhecidas dos ETR, toda a produção decorre da explotação de pláceres de pequeno a médio porte instalados na faixa costeira, principalmente no trecho litorâneo que vai do Rio de Janeiro ao sul da Bahia. Os grandes depósitos, associados a alcalinas (i.e. Catalão, Araxá, Poços de Caldas), permanecem como reservas técnicas dependentes do desenvolvimento de processos economicamente viáveis de beneficiamento do conteúdo de ETR.

Quanto ao Estado de São Paulo, embora o cenário geológico esteja erguido sobre terrenos compatíveis com a existência dos principais metalotectos mundiais dos ETR, o potencial para estes bens minerais pode ser apontado como relativamente baixo. A alteração deste quadro pode se dar pela descoberta de mineralizações associadas a corpos periféricos aos complexos alcalinos conhecidos, ou 
mesmo a novos corpos desta natureza que venham a ser descobertos.

As áreas do Estado com maior potencial para os ETR envolvem depósitos do tipo plácer, cujo significado é auxiliado pelo domínio da técnica de beneficiamento e processamento da monazita-(Ce) detrítica. No entanto, a reduzida dimensão dos virtuais depósitos, aliada aos vários impedimentos ambientais e ocupacionais, surgem como fatores que prejudicam campanhas exploratórias e a instalação de empreendimentos mineiros.

CONCLUSÕES No Estado de São Paulo, o potencial para recursos não descobertos dos ETR mostra-se mais propriamente restrito às faixas sedimentares litorâneas do sul paulista e às bacias de Taubaté e São Paulo, sempre para depósitos do tipo plácer. Pelos dados disponíveis, mesmo nestas situações, estes depósitos deverão ter necessariamente porte muito pequeno a pequeno.

Em particular, se considerada a extensão das seqüências areno-rudáceas do topo da Bacia de Taubaté (conglomerado basal da Formação Pindamonhangaba), e repetindo-se o conteúdo de monazita-(Ce) detectado em ponto deste nível estratigráfico, há a perspectiva de existência de diversos pequenos depósitos nesta província que, em conjunto, poderiam viabilizar sua lavra.

De qualquer modo, a economicidade dos virtuais depósitos tipo plácer dos ETR parece estar subordinada à possibilidade do aproveitamento de bens minerais associados, pesados ou não (i.e. ilmenita, rutilo, zircão ou materiais industriais e para construção civil), e pelo contorno de limitações à explotação impostas por questões ambientais (principalmente na zona costeira) ou de conflito com outras formas de uso e ocupação do solo, como a expansão urbana ou agricultura (caso típico das bacias de São Paulo e'Taubate).

Agradecimentos Os autores agradecem à Secretaria de Ciência, Tecnologia e Desenvolvimento Econômico do Estado de São Paulo (SCTDE)/Programa de Desenvolvimento de Recursos Minerais (PRÓ-MINÉRIO), pelo patrocínio da pesquisa e permissão para utilização de dados; ao Instituto de Pesquisas Tecnológicas do Estado de São Paulo (IPT), pelo apoio à elaboração do trabalho; aos geólogos Francisco E. L. Lapido Loureiro, Jorge Silva Bettencourt e ao Engenheiro de Minas Ayrton Sintoni, pelas sugestões recebidas.

\section{REFERÊNCIAS BIBLIOGRÁFICAS}

ABREU. V. A. 1991. Investigação prospectiva na indústria dos terrasraras; subsídios para política e gestão em minerais/materiais estratégicos. Campinas. 109p. (Dissertação de mestrado apres. I G/ UNICAMP).

ALMEIDA, F.F.M de. 1976. The system of continental rifts bordering the Santos Basin, Brazil. Rio de Janeiro. An. Acad. Bras. Ci., 48(supl.): $15-26$.

ALMEIDA, F.F.M. de. 1983. Relações tectônicas das rochas alcalinas mesozóicas na região meridional da Plataforma Sul-Amerícana. Rev. Bras. Ceoc., 13(3):139-158.

BETEJTIN, A. 1977. A course of mineralogy. Moscou, Peace Publishers. $643 \mathrm{p}$.

BEUS.A.A. 1982. Metallogeny of Precambrian rare-metal granitoids. Rev. Bras. Geoc., 12(1,2,3):410-413.

BIONDI, J.C. 1986. Depósitos de minerais metálicos de filiação magmatica. São Paulo, T.A. Queiroz Ed. 602p.

BORN, H. 1971. O Complexo Alcalino de Juquiá. São Paulo. 174p. (Tese de doutoramento apres. IG/USP)

CABRAL JÚNIOR, M. 1991. Avaliação do Potencial metalogenético da Bacia do Paraná no Estado de São Paulo para depósitos sedimentares fosfáticos, evaporíticos e de metais-base. Rio Claro. 238 p. (Dissertação de mestrado apres. IGCE/UNESP).

COMPANHIA BRASILEIRA DE MINERAÇÃO E METALURGIACBMM. 1984. Complexos carbonaíiticos do Brasil: geologia. São Paulo, CBMM/Departamento de Geologia. 44p.

COMPANHIA DE PESQUISA DE RECURSOS MINERAIS-CPRM. 1975. Projeto Sudelpa; relatório final. São Paulo, Convênio Sudelpa CPRM. $18 \mathrm{v}$

COOK, P.J. 1976. Sedimentary phosphate deposits. In: WOLF, K.H. ed. Handbook of strata-bound and stratiform deposits, s.l., Elsiever. Chapt 11.

COUTINHO, J. M. V; COIMBRA, A. M. BRANDT NETO, M. \& ROCHA, G. A. 1981. Lavas alcalinas analcimíticas associadas ao Grupo Bauru (KB) no Estado de São Paulo, Brasil. In: CONGR. LATINOAMERICANO, 5, Buenos Aires, 1981. Actas... Buenos Aires, SGN: IUGS. v.2, p.185-195.

COX, D.P. \& SINGER, D.A. 1986. Mineral deposit models. Washington, USGS. 379p. (USGS Bulletin, 1963).

DEPARTAMENTO NACIONAL DA PRODUÇÃO MINERAL-DNPM 1973. Perfil analitico do (trio e terras raras. Rio de Janeiro, DNPM. 72p. (DNPM Boletim, 28).

DRYSDALL, A. R.; JACKSON, N. J.; RAMSAY, C. R.; DOUCH, C. J. \& HACKETT, D. 1984. Rare element mineralization related to Precambrian Alkali granites in the Arabian Shield. Econ. Geol., 79:1366-1377.

FERREIRA, F J.F ; MONMA, R ; SILVA, R B da; ALGARTE, J. P ; MARTINS, F.G . A.; RODRIGUES, E. DE P.; THEODOROWICZ, A.; TASSINARI, C. G. C. \& COUTINHO, J. M. V. 1987. A alcalina de Pariquera-Açii. In: SIMP.REG.GEOL., 6, Rio Claro, 1987. Atas... Rio Claro, SBG. v.l, p.159-172

FIGUEIREDO FILHO, P.M. de \& TOREZAN, M.J. 1988. Terras raras. Minérios Extração e Processamento, 12(140):80-82.
FIGUEIREDO FILHO, P.M. de \& TOREZAN, M.J. 1989. Terras raras. Minérios Extração e Processamento, 13(153):61-65.

HASUI, Y. 1963. Sobre os granitos turmaliníferos de Perus, São Paulo-SP. Boletim da SBG, 12(1-2):87-108

HASUI, Y; CARNEIRO, C.D.R. \& BISTRICH, C.A. 1978, Os granitos e granitóides da região de dobramentos sudeste nos Estados de São Paulo e Paraná. In: CONGR.BRAS.GEOL., 30, Recife, 1978. Anais... Recife, SBG. v.6, p.2594-2608.

HENDERSON, P. 1984. General geochemical properties and abundances of the earth elements. In: HENDERSON, P. ed. Rare earth element geochemistry. Amsterdam, Elsevier. 510p.

INSTITUTO DE PESQUISAS TECNOLÓGICAS DO ESTADO DE SÃO PAULO-IPT. 1981a. Mapa geológico do Estado de São Paulo; escala 1:500.000. São Paulo. 2v. (IPT. Monografias, 6).

INSTITUTO DE PESQUISAS TECNOLÓGICAS DO ESTADO DE SÃO PAULO-IPT.1981b. Mapa de jazidas e ocorrências minerais do Estado de São Paulo; escala 1:500.000. São Paulo. 3v. (IPT. Monografias, 4).

INSTITUTO DE PESQUISAS TECNOLÓGICAS DO ESTADO DE SÃO PAULO-IPT. 1984a. Pegmatitos no Estado de São Paulo; potencialidade geológica. São Paulo (IPT. Relatório, 21 548).

INSTITUTO DE PESQUISAS TECNOLÓGICAS DO ESTADO DE SÃO PAULO-IPT.1984b. Projeto Carvão Buri; detalhamento das ocorrências. São Paulo. (IPT. Relatório, 20 549).

INSTITUTO DE PESQUISAS TECNOLÓGICAS DO ESTADO DE SÃO PAULO-IPT. 1988a Sensoriamento remoto aplicado à prospecção mineral; seleção de áreas. São Paulo. 4v. (IPT. Relatório, $26335)$.

INSTITUTO DE PESQUISAS TECNOLÓGICAS DO ESTADO DE SÃO PAULO-IPT. 1988b Avaliação preliminar da geologia das folhas (em 1:50.000), Taquaral, Mina do Espírito Santo, Ribeirão Itacolomi, Serra do Aboboral, Jacupiranga (Eldorado Paulista), Rio Guaraú (Barra do Azeite), Rio Turvo (Serra do Aleixo) - Vale do Ribeira, SP. São Paulo. (IPT. Relatório, 28863 ).

INSTITUTO DE PESQUISAS TECNOLÓGICAS DO ESTADO DE SÃO PAULO-IPT. 1989a. Oportunidades tecnológicas e industriais para minerais estratégicos; estudo dos casos silicio, quartzo e terras raras. São Paulo. 3v. (IPT. Relatório, 27 189).

INSTITUTO DE PESQUISAS TECNOLÓGICAS DO ESTADO DE SÃO PAULO-IPT. 1989b. Compartimentação estrutural e evolução tectônica do Estado de São Paulo. São Paulo. 2v. (IPT. Relatório, 27 394).

JULIANI, C.; BELJAVISKIS, P. \& SCHORCHER, H.D. 1986. Petrogênese do vulcanismo e aspectos metalogenéticos associados: Grupo Serra do Itaberaba na região de São Roque, SP. In: CONGR. BRAS.GEOL., 34, Goiânia, 1986. Anais... Goiânia, SBG. v.2, p.730-749

KAUL, P.F.T. 1984. Significado dos granitos anorogênicos da Suíte Intrusiva Serra do Mar na evolução da crosta do sul-sudeste do Brasil, no âmbito das folhas SG.22 - Curitiba e SG.23 - Iguape. In: CONGR.BRAS.GEOL., 33, Rio de Janeiro, 1984. Anais... Rio de Janeiro, SBG. v.6. p.2815-2825. 
KAUL, P. F. T.; ISSLER, R. S.; FERNANDES, E.; BONOW, C. W \& COUTINHO, J.B.L. 1982. Suíte Intrusiva Serra do Mar. Florianópolis: Projeto RADAM BRASIL. 18p. (Relatório Interno).

KENDALL, A.C. 1984. Evaporites. In: WALKER, R.G. ed. Fades models. 2.ed. St. John's, Geological Association Canadá, p.259-296. (Geoscience Canada Reprint Series, 1).

KNECHT, T. 1938. Nota sobre novas ocorrências de fosfato. São Paulo, IGG. (Notas Prévias, 1).

KNECHT, T. 1950. Ocorrências minerais do Estado de São Paulo. São Paulo, IGG. 145p.

LAMEYRE, J. \& BOWDEN, P. 1982. Plutonic rocks type series Discrimination of various granitoid series and related rocks. Jour. Vole. Ceoth. Res., 14:169-186.

LAZNICKA, P. 1985. Empirical metalogeny: deposicional environments, lithologic associations and mettalic ores, s.1., Elsevier. 2v.il.

LOUREIRO, F. E. L. 1983. Duas novas ocorrências de carbonatitos: Mato Preto e Barra do Rio Itapirapuã. Rev. Bras. Geoc., 1(13):7-11

LOUREIRO, F. E.L. 1988. Terras Raras: onde e porque prospectá-las; tipos de jazimentos; perspectivas mercadológicas. Rio de Janeiro, CPRM. 56p. (Informe Técnico). (Inédito)

LOUREIRO, F.E.L.; FIGUEIREDO, C.M.V. de \& TOREZAN M.J. 1989. Os elementos terras raras nos complexos carbonatfticos brasileiros. In: FORMOSO, M.L.L. NARDI, V. S.; HARTMANN, L. A. ed. Geoquímica dos elementos terras raras no Brasil. Rio de Janeiro, CPRM, DNPM, SBGq. p. 47-59.

MACHADO, I. 1989. Recursos minerais politica e sociedade. São Paulo, Edgard Blücher Ed. 410p.

MELCHER, G.C. 1966. The carbonatites of Jacupiranga, São PauloBrazil. In: TUTTLE, T.O.F. \& GITTINI, J. ed. Carbonatites. New York: John Wiley, p.169-181.

MELO, M.S.; de FERNANDES, L. A.; COIMBRA, A. M. \& RAMOS, R. G. N. 1989. O Gráben (terciário?) de Sete Barras, Vale do Ribeira do Iguape, SP. Rev Bras.Geoc. 19(2):260-262.

MELO, M.S. de.1990. A Formação Pariquera-Açu e depósitos relacionados:.sedimentação, tectônica e geomorfogênese. São Paulo (Disser-

tação de mestrado apres. IG/USP).

MONIZ, A.C. 1964. Estudo mineralógico de argilas do maciço alcalino de Poços de Caldas. São Paulo. 109p. (Tese de doutoramento apres. FFCL/USP).

NEARY, C.R. \& HIGHLEY, D.E. 1984. The economic importance of the rare earth elements. In: HENDERSON, P. ed. Rare earth element geochmistry. Amsterdam, Elsevier. $51 \mathrm{Op}$.

NOGUEIRA FILHO, J. do V; SARAGIOTTO, J.A.R. \& SINTONI, A 1978. A jazida de Apatita de Ipanema. In: CONGR.BRAS.GEOL., 29,
Belo Horizonte, 1978. Anais... Belo Horizonte, SBG. v. 4, p.7 5-87.

OLIVEIRA, A. G. de. 1976. Mineralizacão de Urânio e Molibdênio no Planalto de Pocos de Caldas, MG. In: CONGR.BRAS.GEOL., 28, Porto Alegre, 1976. Anais... Porto Alegre, SBG. v. 1, p. 207-220.

OVERSTREET, W.C.1967. The geologic occurence ofmonazile. Washington, USGS. (USGS Professional Paper, 530).

RIBEIRO FILHO, E. 1958. Nota sobre um depósito aluvionar radioativo Quartenário da Bacia do Paraíba em Tremembé, São Paulo. Eng.Min.Met., 28(160):199-200.

RICCOMINI, C. 1989.0 Rift continental do Sudeste do Brasil. São Paulo. (Tese de doutoramento apres. IG/USP).

SAMITRI. 1984. Minerais pesados; Rio Sapucaí. São Paulo. (Relatório Interno).

SIGOLO, J.B. 1979. Geologia de depósitos residuais bauxíticos na região de Lavrinhas-SP e sua viabilidade econômica. São Paulo. 190p. (Dissertação de mestrado apres.IG/USP).

SLANSKY, M. 1980. Geologic des phosphates sédimentaires. Orleans, BRGM. 92p. (BRGM. Mémoire, 114).

SMIRNOV, VI. 1982. Geologia de yacimientos minerales. Moscou, Ed.Mir. 654p.

SMIRNOV, V.I.; A. I. GINZBURG; GRIGORIEV, V. M. \& YAKOLEV, G. F. 1983. Studies of mineral deposits. Moscou, Ed.Mir. 288p.

SOARES, P.C. 1987. Seqüências Tecto-Sedimentares e Tectônica Deformadora no Centro-Oeste do Escudo Paranaense. In: SIMP.SULBRAS.GEOL., 3, Curitiba, 1987. Anais... Curitiba, SBG. v.2. p.743771.

TESSLER, M.G.(coord-). 1985. Minerais pesados da região costeira e plataforma continental sul do Estado de São Paulo: determinação das assembléias e potencialidade mineral; relatório final. São Paulo, Instituto Oceanográfico/USP: SICCT/PRO-MINERIO.

THEMAG. 1982. Mapeamento geológico e amostragem geoquímica da Folha de São Luiz do Paraitinga; relatório final. São Paulo. v. 1.

ULBRICH, H.H.G.I. \& GOMES, C.B. 1981. Alkaline rocks from continental Brazil. Earth Sc.Rev., 17:135-154.

WERNICK E. \& GALEMBECK, T.M.B. 1986. Caracterização do plutonismo granitóide do ciclo brasiliano no Estado de São Paulo através do método da tipologia do zircão. In: CONGR.BRAS.GEOL., 34, Goiânia, 1986. Anais... Goiânia, SBG. v. 3, p. 1369-1382.

MANUSCRITO A820

Recebido em 31 de agosto de 1994 Revisão do autor em 11 de novembro de 1995 Revisão aceita em 18 de março de 1996 